\title{
Iodine-131 metabolic radiotherapy leads to cell death and genomic alterations through NIS overexpression on cholangiocarcinoma
}

\author{
ANA FILIPA BRITO ${ }^{1,2^{*}}$, ANA MARGARIDA ABRANTES ${ }^{1,2^{*}}$, RICARDO TEIXO $^{1,2}$, ANA SALOMÉ PIRES $^{1,2}$, \\ ANA CLÁUDIA RIBEIRO ${ }^{1}$, RAFAEL FERNANDES FERREIRA ${ }^{3}$, ALEXANDRA MASCARENHAS ${ }^{4}$, TIAGO PUGA $^{1,5}$, \\ MAFALDA LARANJO ${ }^{1,2}$, FRANCISCO CARAMELO ${ }^{1,6}$, ILKA BOIN ${ }^{7}$, DOUGLAS M. JEFFERSON ${ }^{8}$, \\ CRISTINA GONÇALVES ${ }^{2,9}$, RICARDO MARTINS ${ }^{10,11}$, INÊS TAVARES ${ }^{4}$, ILDA PATRÍCIA RIBEIRO ${ }^{2,4}$, \\ ANA BELA SARMENTO-RIBEIRO ${ }^{2,9,12}$, ISABEL MARQUES FERREIRA ${ }^{2,4}$, DOROTEIA SOUZA ${ }^{13}$, \\ JOSÉ GUILHERME TRALHÃO ${ }^{10,11}$ and MARIA FILOMENA BOTELHO ${ }^{1,2}$ \\ ${ }^{1}$ Biophysics Institute, CNC.IBILI, and ${ }^{2}$ Institute for Clinical and Biomedical Research Area of Environment \\ Genetics and Oncobiology, Faculty of Medicine, University of Coimbra, 3000-354 Coimbra, Portugal; ${ }^{3}$ Faculty \\ of Medical Sciences of University of Campinas (FCM/UNICAMP), Campinas, SP 13083-887, Brazil; \\ ${ }^{4}$ Cytogenetics and Genomics Laboratory, Faculty of Medicine, University of Coimbra, 3000-354 Coimbra; \\ ${ }^{5}$ School of Health of Porto, Politechnic Institute of Porto, 4200-072 Porto; ${ }^{6}$ Laboratory of Biostatistics and \\ Medical Informatics, Faculty of Medicine, University of Coimbra, 3000-354 Coimbra, Portugal; ${ }^{7}$ Department of \\ Surgery, Faculty of Medical Sciences of University of Campinas (FCM/UNICAMP), Campinas, SP 13083-887, \\ Brazil; ${ }^{8}$ Tufts University School of Medicine, Department of Integrative Physiology and Pathobiology, Medford, \\ MA 02155, USA; ${ }^{9}$ Laboratory of Oncobiology and Hematology, Applied Molecular Biology and University \\ Clinic of Hematology, Faculty of Medicine, University of Coimbra; ${ }^{10}$ Faculty of Medicine, University of \\ Coimbra, 3000-354 Coimbra; ${ }^{11}$ Serviço de Cirurgia A, and ${ }^{12}$ Departamento de Hematologia, Centro Hospitalar \\ e Universitário de Coimbra, 3004-531 Coimbra, Portugal; ${ }^{13}$ Department of Molecular Biology, Faculty \\ of Medicine of São José do Rio Preto (FAMERP), São José do Rio Preto, SP 15090-000, Brazil
}

Received June 28, 2019; Accepted September 24, 2019

\section{DOI:10.3892/ijo.2020.4957}

\begin{abstract}
Cholangiocarcinoma (CC) is an aggressive liver tumor with limited therapeutic options. Natrium-iodide symporter (NIS) mediates the uptake of iodine by the thyroid, representing a key component in metabolic radiotherapy using iodine-131 $\left({ }^{131} \mathrm{I}\right)$ for the treatment of thyroid cancer. NIS expression is increased in CC, providing the opportunity for a novel therapeutic approach for this type of tumor. Thus, in this study, we aimed to evaluate therapeutic efficacy of ${ }^{131} \mathrm{I}$ in two human CC cell lines. Uptake experiments analyzed the ${ }^{131}$ I uptake profiles of the tumor cell lines under study. The cells were irradiated with various doses of ${ }^{131}$ I to evaluate and characterize the
\end{abstract}

Correspondence to: Professor Maria Filomena Botelho, Biophysics Institute, Center for Neuroscience and Cell Biology and Institute for Biomedical Imaging and Life Sciences (CNC.IBILI), Faculty of Medicine, University of Coimbra, Azinhaga of Santa Comba-Celas, 3000-354 Coimbra, Portugal

E-mail: mfbotelho@fmed.uc.pt

Abbreviations: NIS, natrium-iodide symporter; ${ }^{131} \mathrm{I}$, iodine-131

Key words: cholangiocarcinoma, natrium-iodide symporter, iodine-131, metabolic radiotherapy, gene expression, cell death effects of metabolic radiotherapy. NIS protein expression was assessed by immunofluorescence methods. Cell survival was evaluated by clonogenic assay and flow cytometry was used to assess cell viability, and the type of death and alterations in the cell cycle. The genomic and epigenetic characterization of both $\mathrm{CC}$ cells was performed before and after irradiation. NIS gene expression was evaluated in the CC cells by RT-qPCR. The results revealed that $\mathrm{CC}$ cells had a higher expression of NIS. ${ }^{131} \mathrm{I}$ induced a decrease in cell survival in a dose-dependent manner. With the increasing irradiation dose, a decrease in cell viability was observed, with a consequent increase in cell death by initial apoptosis. Karyotype and array comparative genomic hybridization (aCGH) analyses revealed that both $\mathrm{CC}$ cell lines were near-triploid with several numerical and structural chromosomal rearrangements. NIS gene expression was increased in the TFK-1 and HuCCT1 cells in a time-dependent manner. On the whole, the findings of this study demonstrate that the presence of NIS in cholangiocarcinoma cell lines is crucial for the decreased cell viability and survival observed following the exposure of cholangiocarcinoma cells to ${ }^{131} \mathrm{I}$.

\section{Introduction}

Cholangiocarcinoma (CC) is a malignant tumor originating from epithelial cells lining the biliary tree $(1,2)$. Intrahepatic $\mathrm{CC}$ arises within the liver and extrahepatic $\mathrm{CC}$ in the bile ducts 
along the hepatoduodenal ligament. CC is usually clinically silent or associated with non-specific symptoms in the early stages of the disease $(3,4)$. CCs are relatively rare, although their incidence is increasing worldwide, being second most common primary liver tumor following hepatocellular carcinoma $(1,2,5)$. Intrahepatic and extrahepatic CC are probably dissimilar tumors, and this is supported by recent in vitro evidence, as these neoplasms express diverse proteins, have different cell shapes, doubling times, chromosome alterations and chemosensitivity (6). The therapeutic options for CC are limited due to late diagnosis and need to be adapted to each case. Tumor resection is the only potential cure for CC. However, a number of patients are not considered surgical candidates due to comorbidities or an advanced age $(7,8)$, and the median survival of patients with unresectable tumors is $6-12$ months $(2,7,8)$. Thus, nearly half of patients with $\mathrm{CC}$ are only candidates for palliative treatments $(2,4,9)$. Therefore, the search for more effective therapeutic strategies for $\mathrm{CC}$ is mandatory.

According to recent publications, a significant number of CC cases expresses natrium-iodide symporter (NIS) at the cell membrane, which may represent a key target for a novel therapeutic approach based on metabolic radiotherapy using iodine-131 $\left({ }^{131} \mathrm{I}\right)(10-12)$. NIS is a glycosylated integral membrane protein that mediates the active transport of iodine into cells. Location at cell membrane seems to be essential to iodine uptake (13-15). It is known that thyroid follicular cells exhibit constitutive NIS expression (13). Their ability to accumulate iodine through NIS was the basis for the development of diagnostic tools, but also for use in therapy with ${ }^{131} \mathrm{I}$ to destroy hyperfunctional thyroid tissue, such as tumor tissue and metastases (15). Several publications highlight NIS expression in non-thyroidal tissues, reporting NIS immunostaining in $>15$ types of human tissues and different types of tumors $(10,16-20)$. NIS expression in CC in human tissues was described for the first time in 2007 (10). It was found that NIS is expressed by cholangiocytes of the bile duct epithelium of patients with CC. However, NIS expression found in normal bile duct cells was very low in contrast to the higher expression by proliferating cells, both in tumors and non-tumor areas adjacent to CC samples from the patients included on that study (10). Recently, in 2012, Kim et al demonstrated that in 60 cases of CCs examined, $>98 \%$ of these expressed NIS, although only $33.3 \%$ expressed this protein at the cell membrane (11). Therefore, NIS may be a target for the development of novel therapeutic tools for $\mathrm{CC}$, based on the acquisition and retention of iodine, such as ${ }^{131} \mathrm{I}(10,11)$. Moreover, in extrahepatic CCs, to date, there are no studies available concerning NIS expression, at least to the best of our knowledge.

Metabolic radiotherapy using ${ }^{131} \mathrm{I}$ is already used in the treatment of thyroid disorders, namely for the ablation of remaining thyroid tissue or for the treatment of residual, recurrent or metastatic disease, being one of the most successful anticancer therapies $(21,22)$. Thus, the aim of this study was to elucidate the role of NIS receptor as a potential agent for use in the treatment of $\mathrm{CC}$ with ${ }^{131} \mathrm{I}$ therapy.

\section{Materials and methods}

Cells and cell culture. Human cell lines of extrahepatic CC (TFK-1, Deutsche Sammlung von Mikroorganismen und
Zellkulturen) and intrahepatic CC (HuCCT1, JCRB0425, JCRB Cell Bank) were used, together with the human immortalized non-malignant intrahepatic cholangiocytes cell line, H69 (23). CC cells were cultured according to manufacturer's instructions, in RPMI-1640 (R4130 Sigma-Aldrich) supplemented with 5\% fetal bovine serum (F7524, Sigma-Aldrich), $1 \%$ antibiotic/antimycotic $\left(15240\right.$, Gibco $\left.^{\circledR}\right)$ and sodium pyruvate $\left(11360\right.$, Gibco ${ }^{\circledR}$; Thermo Fisher Scientific) at $400 \mathrm{mM}$, $\mathrm{pH}$ 7.4. H69 cells were cultured as previously described in the study by Hohenester et al (24). The cells were maintained in a humidified atmosphere, $37^{\circ} \mathrm{C}$ and $5 \% \mathrm{CO}_{2}$ [Heraeus HeraCell $150 \mathrm{CO}_{2}$ Incubator (BridgePath Scientific)]. Cells at $<15$ passages were used.

Irradiation with ${ }^{131} I$. Irradiation of the cells with ${ }^{131} \mathrm{I}$ was carried out according to a previously established protocol (25). The cells were exposed to internal radiation with ${ }^{131} \mathrm{I}$ (IBA Molecular) for $5 \mathrm{~min}$, using different activities to achieve different radiation exposure doses as summarized in Tables SI and SII. Following exposure to ${ }^{131} \mathrm{I}$, the cells were washed with phosphate-buffered saline (PBS). Doses were calculated assuming the worst-case scenario, i.e., all the emitted energy in the decay process was absorbed by the cells. The radiation exposure dose was calculated using the following equation:

where ' $\mathrm{D}$ ' represents the absorbed dose $(\mathrm{Gy})$, ' $\mathrm{A}_{0}$ ' represents the initial activity of the radioactive source $(\mathrm{mCi})$, ' $\mathrm{T}_{1 / 2}$ ' represents the half-life (sec), ' $t$ ' represents the irradiation time (sec).

$$
D=\frac{A_{0} T_{1 / 2} e^{\frac{\ln 2}{T 1 / 2} t} \bar{E}}{\ln 2 M}
$$

' $\overline{\mathrm{E}}$ ' represents the average energy per disintegration $(\mathrm{eV})$ and ' $M$ ' represents the sample mass subjected to irradiation $(\mathrm{kg})$.

Determination of NIS protein expression. NIS protein expression was evaluated by immunofluorescence methods. Briefly, $1 \times 10^{5}$ cells were plated in 12 multi-well plates. After $24 \mathrm{~h}$, the cells were irradiated with 20 Gy of ${ }^{131} \mathrm{I}$. At $2 \mathrm{~h}$ post-irradiation, the control and irradiated cells were incubated with anti-NIS primary antibody [NIS (N-15), sc-48055, Santa Cruz Biotechnology] and secondary antibody (Alexa Fluor ${ }^{\circledR} 488$, rabbit anti-goat IgG, A-11078, Life Technologies ${ }^{\circledR}$; Thermo Fisher Scientific) according to the manufacturer's instructions. The cells were then incubated with Hoechst 33342 (B1153, Sigma Aldrich $\left.{ }^{\circledR}\right)$. After processing, the slides were observed under a fluorescence microscope (Leica DM 4000 B). Images were analyzed using Image J version $1.52 \mathrm{~g}$ software to quantify NIS expression (total and membrane).

${ }^{131}$ I uptake analyses. For uptake analyses, a suspension of $\mathrm{CC}$ cells at $2 \times 10^{6}$ cells $/ \mathrm{ml}$ was prepared in $25 \mathrm{~cm}^{2}$ flasks. Subsequently, ${ }^{131} \mathrm{I}$ was added at $9.25 \times 10^{5} \mathrm{~Bq} / \mathrm{ml}$ after achieving steady-state conditions. The samples were removed to microtubes containing cold PBS for uptake determination at 5, 30, 60, 90 and $120 \mathrm{~min}$. During radiotracer uptake analyses, for every sample, the cells were resuspended to ensure uniformity. Cell suspensions were then centrifuged at 5,600 x g for $1 \mathrm{~min}$, at $4^{\circ} \mathrm{C}$. The radioactivity of the cell pellets and supernatants was measured separately with a well-type gamma counter 
(Capintec, Inc. CRC, 25W) to determine the ${ }^{131}$ I uptake percentage. Cell viability was assessed by the trypan blue exclusion test at the conclusion of the experiments, as previously described $(26,27)$. Briefly, a cell suspension was mixed with trypan blue (1:1 ratio). Subsequently, the viable cells, which do not incorporate the trypan blue dye, and dead cells, which are dyed blue, were counted to calculate the percentage of cell viability, and thus, to ensure that cell death did not occur during the experiment. Uptake curves were obtained from modeling to 1st degree systems resulting in exponential equations. The adjustment of these curves to experimental data was performed by the Levenberg-Marquardt optimization method, an algorithm that is an iterative technique that locates the minimum of a function that is expressed as the sum of squares of nonlinear functions $(28,29)$ and $95 \%$ confidence intervals were obtained in addition to coefficients of adjustment. We determined maximal uptake and half-time to each cell line. Matlab R2014a software was used.

Cell survival analysis. Cell survival was evaluated by clonogenic assay (25). Briefly, $1.5 \times 10^{6}$ cells were plated in $25 \mathrm{~cm}^{2}$ flasks and subsequently irradiated with ${ }^{131} \mathrm{I}$ (3.5, 20 and $\left.60 \mathrm{~Gy}\right)$, apart from the control cells. At 12 days post-irradiation, the cells were fixed with methanol and stained with crystal violet for $5 \mathrm{~min}$, at room temperature. Colonies with >50 cells were counted and efficiency plate (EP) and survival factor (SF) were determined.

Viability and cell death. The effects of ${ }^{131} \mathrm{I}$ on cell viability and types of induced cell death were determined by flow cytometry using Annexin-V/propidium iodide (AnV-PI) (KIT Immunotech). Briefly, cells were irradiated with ${ }^{131} \mathrm{I}$ (10, 20 and $60 \mathrm{~Gy})$. After $48 \mathrm{~h}$, the control and irradiated cells were double-labeled with AnV conjugated with fluorescein isothiocyanate (AnV-FITC) and PI as previously described (31).

Cell cycle analysis. For cell cycle analysis, the cells were previously irradiated with 10, 20 and 60 Gy of ${ }^{131} \mathrm{I}$. After $48 \mathrm{~h}$, the control and irradiated cells were fixed and incubated as previously described (31).

Analysis of NIS gene expression. Total RNA was extracted using TRIzol ${ }^{\circledR}$ reagent $\left(\right.$ Ambion $^{\circledR}$ ) and quantified in a QUBIT 2.0 fluorometer according to the manufacturer's instructions. First-strand cDNA was synthesized using the High Capacity cDNA $^{\circledR}$ kit (Applied Biosystems). Transcription levels were normalized to the GAPDH and $\beta$-actin genes and the qPCR reaction was conducted using the StepOne Plus ${ }^{T M}$ Real Time-PCR ${ }^{\circledR}$ system (Applied Biosystems). The samples were processed at $95^{\circ} \mathrm{C}$ for $10 \mathrm{~min}$, followed by 40 cycles at $95^{\circ} \mathrm{C}$ for $15 \mathrm{sec}$ and $60^{\circ} \mathrm{C}$ for $1 \mathrm{~min}$. The oligonucleotide primers were purchased from Thermo Fisher Scientific and were as follows: NIS, Hs00166567_m1; GAPDH, Hs02786624_g1 and Hs01060665_g1. NIS relative gene expression was determined by the $2^{-\Delta \Delta \mathrm{Cq}}$ comparative method, which relates the mean expression of normalizing genes used as an endogenous control and the mean expression of genes of interest (32). All samples were tested in triplicate and expressed as the relative difference of n-times in relation to calibrator (controls). Negative controls were included for all reactions.
Karyotyping. Metaphase chromosomes from the TKF-1 and HuCCT1 cells without treatment and from cells irradiated with 1, 20 and 60 Gy of ${ }^{131}$ I were prepared and analyzed by GTG-banding using standard protocols (33). Briefly, the chromosomes of 32 metaphases were analyzed and then metaphases were digitally imaged and karyotyped resorting to a microscope (Eclipse-400, Nikon) and karyotyped using a Cytovision software version 3.93.2 (Applied Imaging System).

DNA extraction. DNA from the CC cells treated with or without irradiation and from the control cultured cells of gingival tissue obtained from healthy patients undergoing surgical removal of wisdom teeth was extracted using the High Pure PCR Template Preparation kit (Roche GmbH), according to the manufacturer's recommendations. The DNA concentration and purity were measured using a NanoDrop1000 Spectrophotometer (Thermo Fisher Scientific).

Array $\mathrm{CGH}$. High-resolution whole genome analyses (aCGH) were performed using Agilent SurePrint G3 Human Genome microarray $180 \mathrm{~K}$ (Agilent Technologies), as previous described (34). DNA of both cell lines without irradiation and those treated with $60 \mathrm{~Gy}$ were labeled with Cy5 by random primer labeling. DNA from a male commercial control (Agilent Technologies) was labeled with Cy3. The results were analyzed using Agilent Genomic Workbench v6.5 software with the following settings: ADM2 as aberration algorithm, threshold of 6.0 , moving average $2 \mathrm{Mb}$. The 3 are according to Human Genome build 19 and include imbalances with at least three consecutive probes with abnormal $\log 2$ ratios. The results are presented accordingly to GRCh37/hg19.

Methylation-specific multiplex ligation-dependent probe amplification (MS-MLPA). MS-MLPA analyses were performed using ME002 probemix (MRC-Holland), which can simultaneously detect copy number alterations (CNAs) in 38 tumor suppressor genes and aberrant methylation patterns in a subset of 25 of these genes as previously described (33). All MS-MLPA reactions were performed according to a previous study (35) using DNA from both cell lines and all doses of irradiation.

Statistical analysis. Statistical analysis was performed using IBM SPSS v.20 software (IBM Corp.). In descriptive analysis, measures of central tendency (mean and median) and dispersion (standard deviation and interquartile range) for quantitative variables were determined. The normal distribution of these variables was assessed using the Shapiro-Wilk test. For normal underlying distributions, parametric tests were used and non-parametric tests in the opposite case. Comparisons of quantitative variables between 2 groups were performed using a Student's t-test (parametric) and the Mann-Whitney U test (non-parametric). Comparisons of quantitative variables between $>2$ groups were carried out using one-factor ANOVA with post hoc analysis using Tukey's test (parametric tests) and the Kruskal-Wallis test, with multiple comparisons performed using the Mann-Whitney U test with the Bonferroni correction. To analyze the results of clonogenic assay, data were adjusted to linear quadratic model using 
OriginalLab v.8.0 software. A significance level of 5\% was considered and a value of $\mathrm{P}<0.05$ was considered to indicate statistically significant differences.

As described above, for uptake assays, the curves were obtained from modeling to 1 st degree systems resulting in exponential equations. Following the adjustment of these curves to experimental data, $95 \%$ confidence intervals were obtained in addition to coefficients of adjustment. Significant differences are considered when there was no overlap of the $95 \%$ confidence intervals.

\section{Results}

NIS protein expression. NIS protein expression in the CC and cholangiocytes was assessed by immunofluorescence. Representative images of NIS expression in the CC and cholangiocytes (membrane and total), the controls and following irradiation (20 Gy), as well as quantification as mean intensity of fluorescence (MIF) are presented in Fig. 1.

As shown in Fig. 1A, the TFK-1 and HuCCT1 CC cells exhibited a higher NIS expression compared to the cholangiocytes. MIF quantification revealed that NIS expression was cell line-dependent. In the cholangiocytes (H69 cells, Fig. 1B), in the controls, total NIS expression was significantly higher than membrane expression $(5.05 \pm 0.99$ vs. $3.03 \pm 0.24$; $\mathrm{P}<0.001)$. The total NIS expression in the controls was also significantly higher than the total expression following exposure to $20 \mathrm{~Gy}$ of ${ }^{131} \mathrm{I}(2.13 \pm 0.30 ; \mathrm{P}<0.001)$. Moreover, the membrane expression in the control cells was significantly higher compared to the membrane expression following exposure to ${ }^{131} \mathrm{I}(1.88 \pm 0.06$, $\mathrm{P}=0.002$ ).

In the TFK-1 cells (Fig. 1C), in the controls, no significant differences were observed between the NIS total and membrane expression (18.50 \pm 2.99 vs. 17.85 \pm 2.49$)$. NIS total expression was significantly higher in the controls than following exposure to ${ }^{131} \mathrm{I}(14.48 \pm 2.20 ; \mathrm{P}<0.001)$. The membrane expression in the control cells was also significantly higher than following exposure to ${ }^{131} \mathrm{I}(13.01 \pm 2.47 ; \mathrm{P}<0.001)$. Additionally, the NIS total expression following exposure to ${ }^{131} \mathrm{I}$ was significantly higher compared to membrane expression $(\mathrm{P}=0.029)$.

As regards the HuCCT1 cells (Fig. 1D), in the controls, no significant differences were observed between NIS total and membrane expression $(12.60 \pm 1.75$ vs. $12.16 \pm 1.38)$. No differences were also observed between total NIS expression in the control cells and the irradiated cells (11.79 \pm 1.11$)$. Moreover, NIS membrane expression was significantly higher in the control cells compared to the irradiated cells $(9.08 \pm 1.31$; $\mathrm{P}<0.001)$. Following exposure to $20 \mathrm{~Gy}$, the total NIS expression was significantly higher compared to membrane expression $(\mathrm{P}<0.001)$.

The results of the comparison of NIS expression between cell lines are described in Fig. 1E (total NIS expression) and Fig. 1F (membrane NIS expression). In the control cells, total NIS expression was significantly lower in the H69 cells compared to the TFK-1 cells $(\mathrm{P}<0.001)$ and HuCCT1 $(\mathrm{P}<0.001)$ cells. In the controls, the TFK-1 cells exhibited a higher NIS total expression compared to the HuCCT1 cells $(\mathrm{P}<0.001)$. As regards NIS membrane expression, in the control cells, the expression was significantly lower in the H69 compared to the TFK-1 $(\mathrm{P}<0.001)$ and HuCCT1 $(\mathrm{P}<0.001)$ cells. The TFK-1 cells exhibited a higher NIS membrane expression in the control cells, compared to the HuCCT1 cells $(\mathrm{P}<0.001)$ (Fig. 1E and F).

Following exposure to ${ }^{131} \mathrm{I}$, differences in NIS expression were observed between the cholangiocytes and CC cells. Thus, the H69 cholangiocytes presented a significantly lower NIS total expression compared to the CC cells TFK-1 $(\mathrm{P}<0.001)$ and HuCCT1 $(\mathrm{P}<0.001)$. The TFK-1 cells exhibited a higher NIS expression compared to the HuCCT1 cells $(\mathrm{P}<0.001)$. As regards NIS membrane expression following irradiation, the H69 cells exhibited a significantly lower expression compared to the TFK-1 and HuCCT1 cells $(\mathrm{P}<0.001)$ (Fig. 1E and F).

${ }^{131}$ I uptake. Following incubation of the cell lines with ${ }^{131} \mathrm{I}$, we determined the ${ }^{131} \mathrm{I}$ profile. The results (Table I) revealed a significant increase in the maximal uptake value when comparing the HuCCT1 (0.13\%; 95\% CI: 0.11-0.15\%) with the TFK-1 cells $(0.20 \%$; $95 \%$ CI: $0.19-0.21 \%)$. As regards the half-life time, the results revealed no statistically significant differences between the two cell lines.

Cell survival. We evaluated effects of irradiation with ${ }^{131} \mathrm{I}$ on the survival of cholangiocytes (Fig. 2A) and the TFK-1 (Fig. 2B) and HuccT1 (Fig. 2C) CC cells by clonogenic assay. In the cholangiocytes, we observed a significant increase in cell survival following exposure to 3.5 Gy $(116.95 \pm 6.21 \%$; $\mathrm{P}<0.001)$ and a statistically significant decrease following exposure to $20 \mathrm{~Gy}(81.85 \pm 8.54 \%$; $\mathrm{P}<0.001)$, with no statistically significant difference observed at $60 \mathrm{~Gy}(106.21 \pm 4.37 \%)$, compared to the controls. Cell survival following exposure to $3.5 \mathrm{~Gy}$ was statistically significantly higher compared to that at $20 \mathrm{~Gy}(\mathrm{P}<0.001)$ and $60 \mathrm{~Gy}(\mathrm{P}=0.004)$. Cell survival following exposure to $20 \mathrm{~Gy}$ was significantly lower compared to that at $60 \mathrm{~Gy}(\mathrm{P}<0.001)$ (Fig. 2A).

In the TKF-1 cells, irradiation with 3.5 Gy significantly decreased cell survival compared to the controls (72.42 $\pm 3.85 \%$; $\mathrm{P}<0.001)$. Irradiation with 20 and $60 \mathrm{~Gy}$ induced a significant decrease in cell survival compared to the controls, $(38.73 \pm 2.51 \%$; $\mathrm{P}<0.001$ for $20 \mathrm{~Gy}$ and $32.42 \pm 7.52 \% ; \mathrm{P}<0.001$ for $60 \mathrm{~Gy}$ ). Cell survival following irradiation with $3.5 \mathrm{~Gy}$ was significantly higher compared to that at $20 \mathrm{~Gy}(\mathrm{P}<0.001)$ and 60 Gy $(\mathrm{P}<0.001)$ (Fig. 2B).

The HuCCT1 cells exhibited a significant decrease in cell survival following exposure to $3.5 \mathrm{~Gy}(37.48 \pm 11.96 \% \%$; $\mathrm{P}<0.001), 20 \mathrm{~Gy}(28.43 \pm 4.50 \% \% ; \mathrm{P}<0.001)$ and $60 \mathrm{~Gy}$ (7.17 $\pm 2.80 \% \% ; \mathrm{P}<0.001)$, compared to the controls. Moreover, cell survival decreased with the increasing radiation doses, as cell survival was significantly lower following irradiation with 60 Gy compared to that at 3.5 and $20 \mathrm{~Gy}(\mathrm{P}<0.001)$ and cell survival following irradiation with 20 Gy was significantly lower compared to that at $3.5 \mathrm{~Gy}(\mathrm{P}=0.034)$ (Fig. 2C).

Depending on the cell line, irradiation with ${ }^{131} \mathrm{I}$ promoted varying effects on cell survival. In a general, the survival of the CC cells decreased as the ${ }^{131} \mathrm{I}$ irradiation dose increased. The intrahepatic HuCCT1 CC cells were more sensitive to irradiation with ${ }^{131} \mathrm{I}$. We observed that the survival of the cholangiocytes was higher than that of the TFK-1 and HuCCT1 cells $(\mathrm{P}<0.001)$ following exposure to ${ }^{131} \mathrm{I}$ for all doses (Fig. 2D). Considering these results, the analyses of the effects of ${ }^{131} \mathrm{I}$ and cytogenetic analyses were only performed on the CC cell lines. 
A
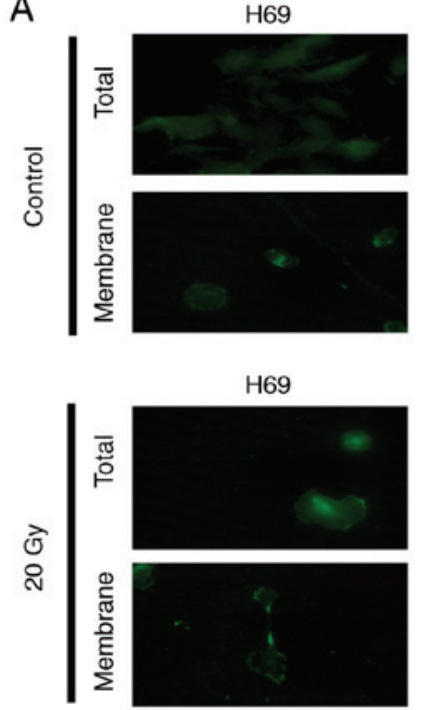

TFK 1
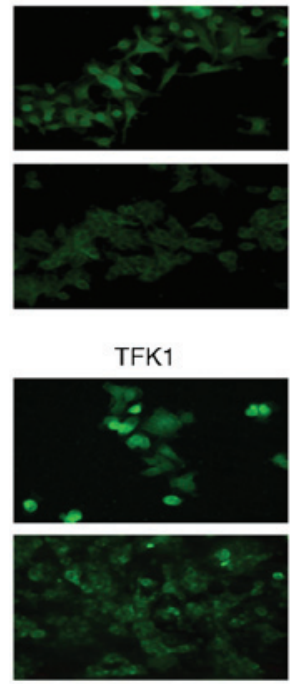

HuCCT1

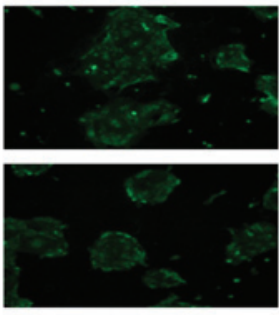

HuCCT1

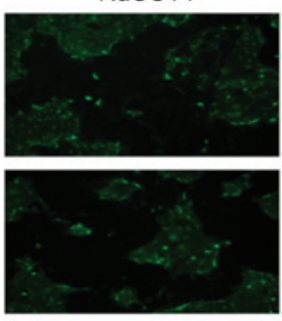

B

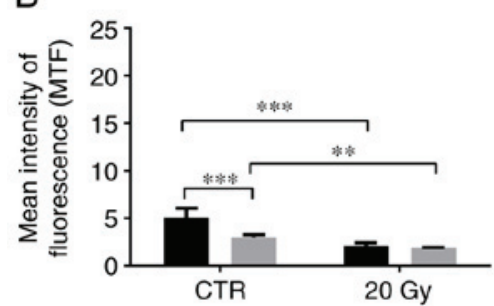

C

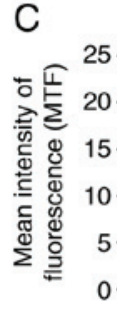

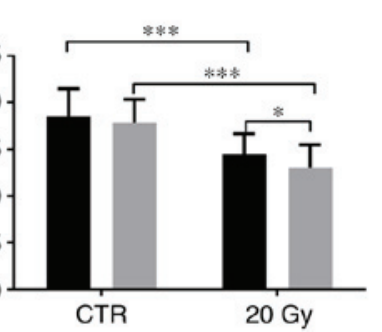
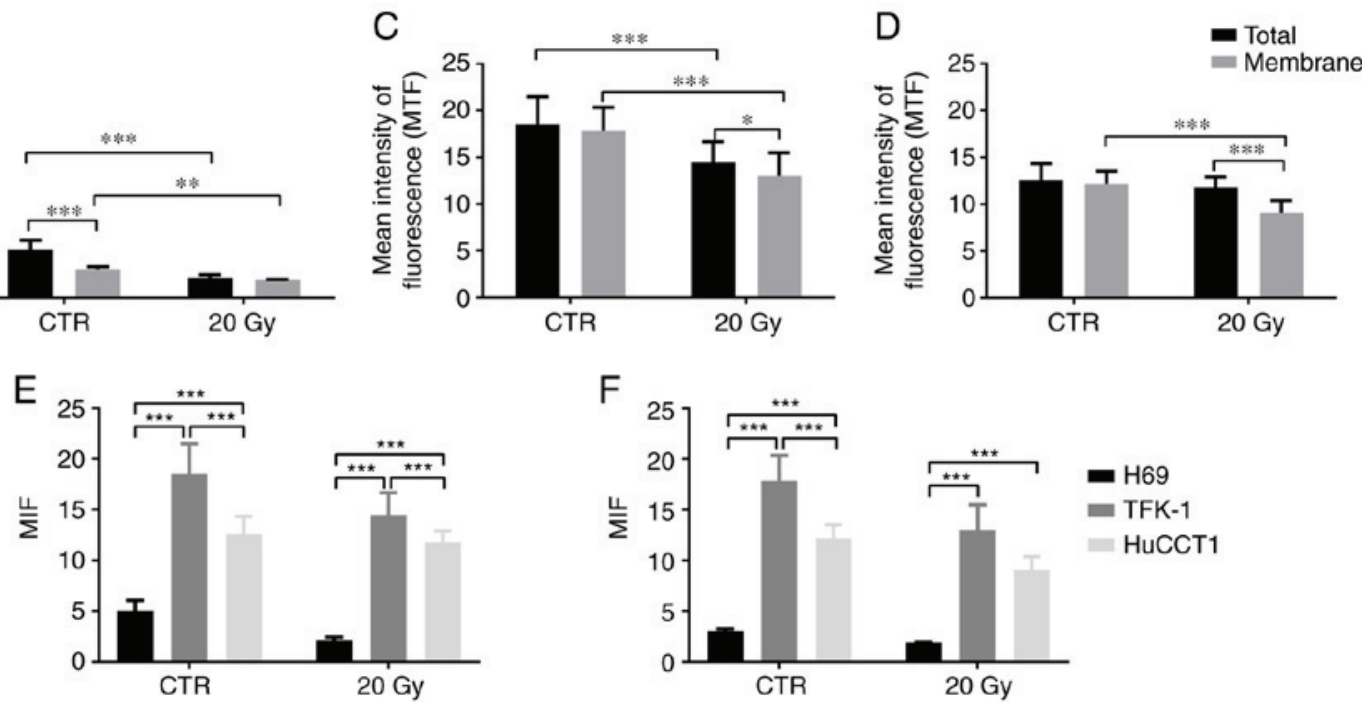

F

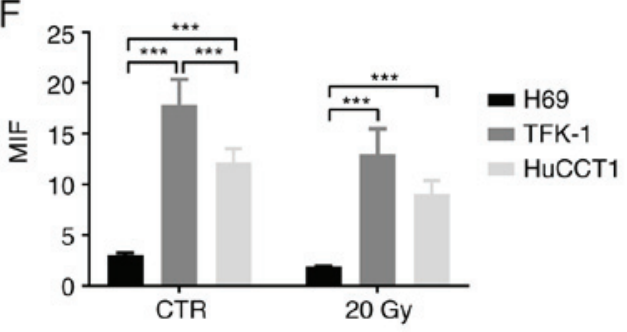

Figure 1. NIS protein expression examined by immunofluorescence. Representative images (A) of NIS expression in cholangiocytes (H69 cells) and cholangiocarcinoma cell lines, TFK-1 and HuCCT1, obtained by immunofluorescence. Images represent NIS total and membrane expression on control cells and cells exposed to $20 \mathrm{~Gy}$ of ${ }^{131} \mathrm{I}$. NIS expression as the mean intensity of fluorescence in (B) H69, (C) TKF-1 and (D) HuCCT1cells. (E) Total NIS expression and (F) membrane NIS expression of all cell lines are expressed as mean intensity of fluorescence (MIF). Results were obtained with a minimum of 3 experiments. Graphs represent the means \pm standard error. Statistical significant differences are identified with an asterisk $(*)$. ${ }^{*} \mathrm{P}<0.05,{ }^{* *} \mathrm{P}<0.01$ and ${ }^{* * *} \mathrm{P}<0.001 . \mathrm{NIS}$, natrium-iodide symporter; ${ }^{131} \mathrm{I}$, iodine-131.

Cell viability and cell death. We evaluated cell viability and the type of cell death following irradiation with ${ }^{131} \mathrm{I}$ by Annexin V-FITC and propidium iodide double labeling. The results (Fig. 2E and F) revealed that cell viability and the type of cell death were highly dependent on the cell line and irradiation dose. In the TFK-1 cells (Fig. 2E), irradiation induced a significant decrease in cell viability following irradiation with 10 Gy $(67.17 \pm 5.42 \%$; $\mathrm{P}<0.001), 20$ Gy $(63.50 \pm 4.09 \%$; $\mathrm{P}<0.001)$ and $60 \mathrm{~Gy}(61.00 \pm 3.63 \% ; \mathrm{P}<0.001)$, compared to the controls $(89.17 \pm 3.19 \%)$. The decreased cell viability was due to the increased percentage of cells in initial apoptosis following radiation with $10 \mathrm{~Gy}(23.83 \pm 7.57 \%$; $\mathrm{P}=0.013), 20 \mathrm{~Gy}$ $(27.83 \pm 5.31 \%$; $\mathrm{P}<0.001)$ and $60 \mathrm{~Gy}(31.17 \pm 5.56 \% ; \mathrm{P}<0.001)$, compared to the controls $(4.83 \pm 1.83 \%)$. No significant alterations in cells undergoing cell death by late apoptosis/necrosis and necrosis were observed following irradiation, compared to the controls.
The irradiated HuCCT1 cells (Fig. 2F) exhibited no significant alterations in cell viability compared to the control cells. However, we observed a statistically significant increase in the number of cells undergoing cell death by apoptosis following irradiation with 10 Gy $(4.25 \pm 0.50 \% ; \mathrm{P}=0.002), 20$ Gy $(6.25 \pm 1.26 \% ; \mathrm{P}=0.015)$ and $60 \mathrm{~Gy}(6.00 \pm 0.82 \% ; \mathrm{P}=0.002)$, compared to the controls $(1.25 \pm 0.50 \%)$. Irradiation with ${ }^{131} \mathrm{I}$ did not significantly alter the number of cells undergoing late apoptosis/necrosis and necrosis.

Cell cycle alterations. Exposure of the CC cells to ${ }^{131} \mathrm{I}$ led to cell cycle arrest in the different phases. In the TFK-1 cells (Fig. 2G), no marked changes were observed in the pre-apoptotic peak following irradiation with $10 \mathrm{~Gy}(1.75 \pm 1.50 \%)$, 20 Gy $(2.00 \pm 0.00 \%)$ and $60 \mathrm{~Gy}(1.33 \pm 0.58 \%)$, compared to the controls $(1.00 \pm 0.82 \%)$. As regards cells in the $\mathrm{G}_{0} / \mathrm{G}_{1}$ phase, no statistically significant differences were observed 
Table I. ${ }^{131}$ I uptake by the CC cell lines TFK-1 and HuCCT1.

Maximal uptake

Half-time

\begin{tabular}{|c|c|c|c|c|c|}
\hline \multirow[b]{2}{*}{ Cell line } & & & \multirow[b]{2}{*}{$\mathrm{r}^{2}$} \\
\hline & Average (\%) & $95 \% \mathrm{CI}$ & Average (\%) & $95 \% \mathrm{CI}$ & \\
\hline TFK-1 & 0.20 & $0.19-0.21$ & 3.30 & $2.56-4.04$ & 0.94 \\
\hline НuCCT1 & 0.13 & $0.11-0.15$ & 1.58 & $-0.27-3.44$ & 0.64 \\
\hline
\end{tabular}

The results are expressed as maximal uptake and half-time, with the $95 \%$ confidence interval (CI), with a minimum of 3 experiments performed in duplicate. CC, cholangiocarcinoma; ${ }^{131}$ I, iodine-131. The $r^{2}$ value represent the coefficient of adjustment to the uptake curves obtained from the experimental data.

following irradiation with 10 Gy $(57.50 \pm 2.51 \%), 20$ Gy $(57.00 \pm 3.16 \%)$ and 60 Gy $(57.17 \pm 1.60 \%)$, compared to the controls $(61.72 \pm 5.71 \%)$. Similarly, there were no significant alterations in the percentage of TFK-1 cells blocked in the S phase following irradiation with 10 Gy $(28.33 \pm 3.08 \%)$, $20 \mathrm{~Gy}(28.83 \pm 2.64 \%)$ and $60 \mathrm{~Gy}(25.83 \pm 1.47 \%)$, compared to the control cells $(27.20 \pm 4.16 \%)$. As regards the $\mathrm{G}_{2} / \mathrm{M}$ phase, we observed a tendency towards a higher number of cells blocked in this phase following irradiation with 10 Gy (14.12 $\pm 2.23 \%), 20 \mathrm{~Gy}(14.17 \pm 3.31 \%)$ and $60 \mathrm{~Gy}(17.00 \pm 063 \%)$, compared to the controls $(12.13 \pm 1.55 \%)$.

In the HuCCT1 cells (Fig. 2H), there were no statistically significant alterations observed in the cells at the apoptotic peak (pre-G0) following irradiation with $10 \mathrm{~Gy}(0.25 \pm 0.50 \%)$, 20 Gy $(0.25 \pm 0.50 \%)$ and 60 Gy $(0.75 \pm 0.50 \%)$, compared to the controls $(0.00 \pm 0.00 \%)$. However, a tendency towards an increased number of cells in the pre- $\mathrm{G}_{0}$ phase was observed. As regards the $G_{0} / G_{1}$ phase, no statistically significant differences were observed following irradiation with $10 \mathrm{~Gy}(61.25 \pm 0.50 \%)$, $20 \mathrm{~Gy}(59.25 \pm 0.50 \%)$ and $60 \mathrm{~Gy}(58.00 \pm 1.83 \%)$, compared to the controls $(57.50 \pm 8.10 \%)$. Irradiation with ${ }^{131} \mathrm{I}$ did not alter the percentage of cells arrested in the $\mathrm{S}$ phase even following irradiation with $10 \mathrm{~Gy}(20.50 \pm 2.38 \%), 20 \mathrm{~Gy}(21.75 \pm 3.20 \%)$ and 60 Gy $(20.25 \pm 3.86)$, compared to the controls $(26.25 \pm 6.08 \%)$. No statistically significant differences were observed in the cells in the $\mathrm{G}_{2} / \mathrm{M}$ phase following irradiation with $10 \mathrm{~Gy}$ (18.25 $\pm 2.75 \%), 20 \mathrm{~Gy}(18.75 \pm 3.20 \%)$ and $60 \mathrm{~Gy}(21.75 \pm 5.56 \%)$, compared to the controls $(16.25 \pm 2.06 \%)$.

As for the differences between the CC cells, we observed a significantly higher percentage of TFK-1 cells in the pre-apoptotic peak following irradiation with $20 \mathrm{~Gy}$ compared with the HuCCT1 cells $(\mathrm{P}=0.037)$. We also observed a statistically significant higher percentage of TFK-1 cells blocked in the $\mathrm{S}$ phase following irradiation with $10 \mathrm{~Gy}$ compared to the HuCCT1 cells ( $\mathrm{P}=0.026$ ) (Fig. 2I).

mRNA NIS expression. NIS mRNA expression was evaluated in the TFK-1 and HuCCT1 CC cells. The results (Table II) are expressed relative to the control cells, at 2, $48 \mathrm{~h}$ and 12 days following irradiation with 1,20 and $60 \mathrm{~Gy}$.

In the TFK-1 cells, irradiation with 1 Gy induced a significant increase in NIS mRNA expression over time $(2 \mathrm{~h}$, $3.477 \pm 0.195 ; 48$ h, $5.087 \pm 0.103$; and 12 days, $11.718 \pm 0.183$; $\mathrm{P}=0.049$ ). Following irradiation with $20 \mathrm{~Gy}$, NIS mRNA expression increased at $48 \mathrm{~h}(9.205 \pm 0.327)$, compared to
$2 \mathrm{~h}(0.748 \pm 0.160 ; \mathrm{P}=0.002)$. A significant decrease was then observed after 12 days, compared to $48 \mathrm{~h}$ following irradiation (5.759 $\pm 0.103 ; \mathrm{P}=0.002)$. Following irradiation with $60 \mathrm{~Gy}$, we observed an increase in NIS mRNA expression over time $(2 \mathrm{~h}$, $2.473 \pm 0.143 ; 48 \mathrm{~h}, 4.688 \pm 0.490$; and 12 days, $5.426 \pm 0.289$; $\mathrm{P}=0.003$ ). The results at $2 \mathrm{~h}$ following irradiation revealed a higher NIS gene expression $(\mathrm{P}=0.03)$ following irradiation with $1 \mathrm{~Gy}$, compared to that at 20 and $60 \mathrm{~Gy}(\mathrm{P}=0.03)$. Moreover, at $48 \mathrm{~h}$ following irradiation, we observed differences in mRNA NIS expression dependent on the dose of exposure. There was a significant increase in NIS gene expression following irradiation with $20 \mathrm{~Gy}$ compared with $1 \mathrm{~Gy}(\mathrm{P}=0.03)$. On the other hand, exposure to 60 Gy induced a decreased mRNA NIS expression, compared to exposure to $20 \mathrm{~Gy}(\mathrm{P}=0.03)$. The NIS gene expression levels decreased with the increasing doses from 1 to $20 \mathrm{~Gy}$ and $60 \mathrm{~Gy}$, at 12 days following irradiation, with differences observed between 1 and $20 \mathrm{~Gy}$ and between 1 and $60 \mathrm{~Gy}(\mathrm{P}=0.02)$.

In the HuCCT1 cells, following irradiation with $1 \mathrm{~Gy}$, we observed a significant increase in NIS mRNA expression with the increasing time following exposure $(2 \mathrm{~h}$, $0.000132 \pm 0.000028 ; 48$ h, 3.736 $\pm 0.086, \mathrm{P}=0.003$; and 12 days, $7.407 \pm 0.390, \mathrm{P}=0.003)$. Moreover, we observed an increase in NIS mRNA expression over time following irradiation with 20 Gy $(2 \mathrm{~h}, 0.0189 \pm 0.0002 ; 48$ h, $4.059 \pm 0.403$, $\mathrm{P}=0.003$ and 12 days: $7.006 \pm 0.593, \mathrm{P}=0.003$ ). The results revealed an increase in NIS mRNA expression following irradiation with 60 Gy after $48 \mathrm{~h}(0.964 \pm 0.037)$ compared to $2 \mathrm{~h}$ $(0.0215 \pm 0.0008, P=0.003)$, followed by a significant decrease after 12 days $(0.000050 \pm 0.000004, \mathrm{P}=0.003)$.

At $2 \mathrm{~h}$ of evaluation, NIS gene expression gradually increased with the increasing doses, as we observed a significant increase at the dose of $60 \mathrm{~Gy}$, compared to $1 \mathrm{~Gy}(\mathrm{P}=0.049)$. The results obtained at $48 \mathrm{~h}$ following irradiation revealed an increased NIS gene expression between doses of 1 and $20 \mathrm{~Gy}$, with a subsequent significant decrease in $60 \mathrm{~Gy}(\mathrm{P}=0.049)$. At 12 days following irradiation, the NIS gene expression levels were very similar between 1 and 20 Gy. However, a tendency towards decreased levels between the above-mentioned doses and 60 Gy was observed.

Cytogenetic analysis. Numerical and structural chromosomal abnormalities (Fig. 3A and B) were found in both cell lines, that are near-triploid with an average number of 70 chromosomes. Shared numeric alterations in both cell lines were observed, 

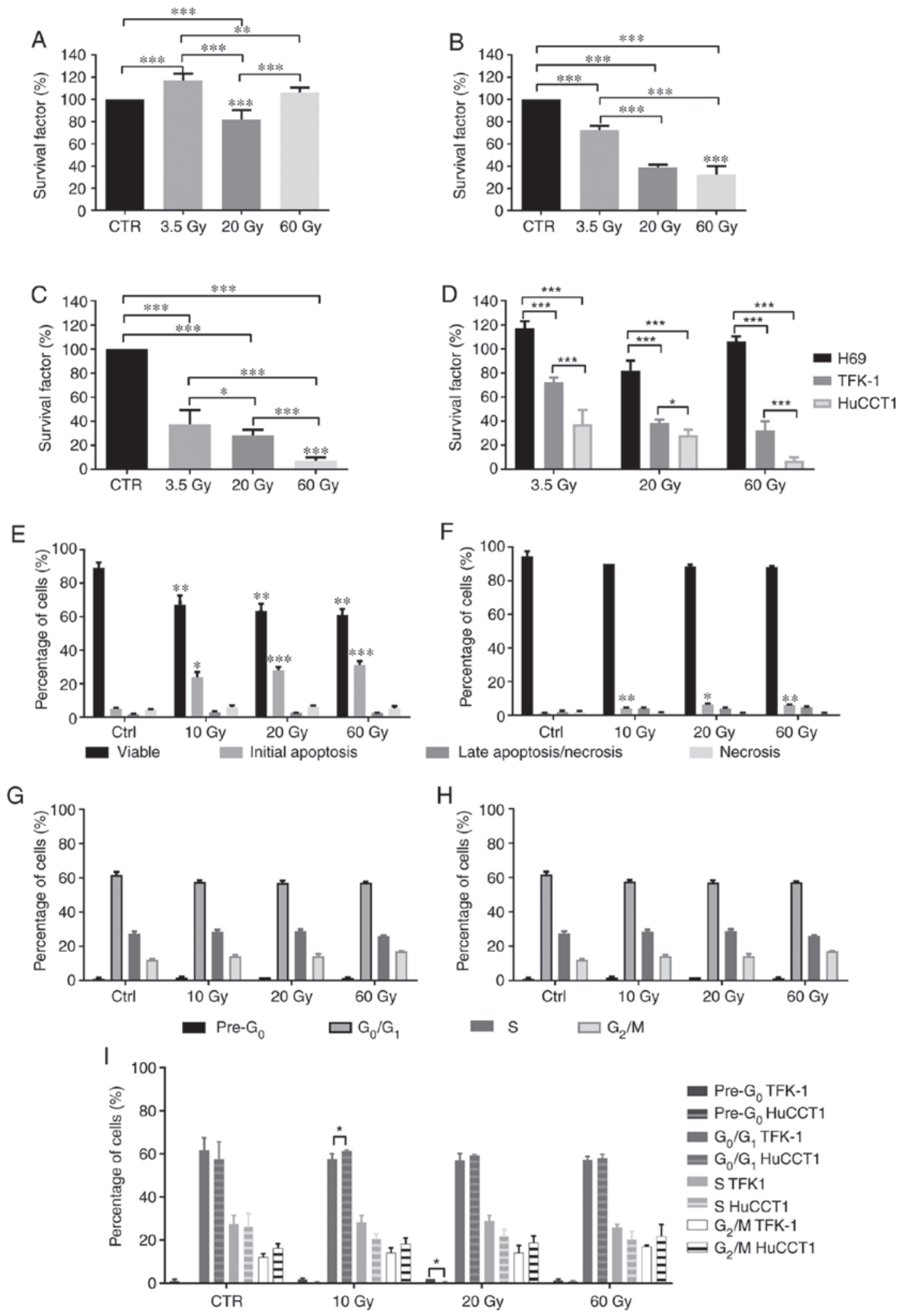

Figure 2. Effects of irradiation with ${ }^{131} \mathrm{I}$ on cell survival (A-D), cell viability (E and F) and cell cycle (G-I). Cell survival was assessed by clonogenic assay, and expressed as a percentage of the survival factor of the cholangiocyte cell line H69 (A) and CC cells TFK-1 (B) HuCCT1 (C) and comparison between all three cell lines (D) Cell viability and type of cell death assessed by AnV-IP double labeling, expressed as a percentage of cells, in CC cell lines (E) TFK-1 and (F) HuCCT1. Evaluation of cell cycle alterations as assessed by propidium iodide labeling in CC cells (G) TFK-1 and (H) HuCCT1, as well as comparison between the two CC cell lines (I) are expressed as a percentage of cell blockade at each cell cycle phase. The results for each analysis are expressed as the means \pm standard error and were obtained with a minimum of 3 independent experiments in duplicate. Statistical significant differences are identified with an asterisk $(*) .{ }^{*} \mathrm{P}<0.05,{ }^{* *} \mathrm{P}<0.01$ and ${ }^{* * *} \mathrm{P}<0.001$. NIS, natrium-iodide symporter; ${ }^{131} \mathrm{I}$, iodine-131.

namely extra chromosomes 1 and 5 . Chromosomes 13 and 18 were lost in both cell lines. Structural chromosome alterations were frequently found, such as gains of material, particularly in chromosomes 1, 5, 11, 14 and 20 (Table III). Other structural 
Table II. mRNA expression of NIS.

Time of evaluation following ${ }^{131}$ I exposure

\begin{tabular}{|c|c|c|c|c|c|c|}
\hline \multirow[b]{2}{*}{ Dose (Gy) } & \multicolumn{2}{|r|}{$2 \mathrm{~h}$} & \multicolumn{2}{|c|}{$48 \mathrm{~h}$} & \multicolumn{2}{|c|}{12 days } \\
\hline & TFK-1 & HuCCT1 & TFK-1 & HuCCT1 & TFK-1 & HuCCT1 \\
\hline 1 & $3.477 \pm 0.195$ & $0.000132 \pm 0.000028$ & $\begin{array}{l}5.087 \pm 0.103 \\
\mathrm{P}=0.049^{\mathrm{a}}\end{array}$ & $\begin{array}{c}3.736 \pm 0.086 \\
P=0.003^{\mathrm{a}}\end{array}$ & $\begin{array}{c}11.718 \pm 0.183 \\
\mathrm{P}=0.049^{\mathrm{a}}\end{array}$ & $\begin{array}{c}7.407 \pm 0.390 \\
\mathrm{P}=0.003^{\mathrm{a}}\end{array}$ \\
\hline 20 & $\begin{array}{c}0.748 \pm 0.160 \\
P=0.003^{\mathrm{d}}\end{array}$ & $0.0189 \pm 0.0002$ & $\begin{array}{c}9.205 \pm 0.327 \\
P=0.002^{\mathrm{b}} \\
\mathrm{P}=0.03^{\mathrm{e}}\end{array}$ & $\begin{array}{c}4.059 \pm 0.403 \\
P=0.003^{b}\end{array}$ & $\begin{array}{c}5.759 \pm 0.103 \\
\mathrm{P}=0.002^{\mathrm{b}} \\
\mathrm{P}=0.02^{\mathrm{f}}\end{array}$ & $\begin{array}{c}7.006 \pm 0.593 \\
P=0.003^{b}\end{array}$ \\
\hline 60 & $\begin{array}{c}2.473 \pm 0.143 \\
P=0.003^{\mathrm{d}}\end{array}$ & $\begin{array}{c}0.0215 \pm 0.0008 \\
P=0.049^{\mathrm{d}}\end{array}$ & $\begin{array}{c}4.688 \pm 0.490 \\
P=0.003^{\mathrm{c}} \\
\mathrm{P}=0.03^{\mathrm{e}}\end{array}$ & $\begin{array}{c}0.964 \pm 0.037 \\
P=0.003^{\mathrm{c}} \\
\mathrm{P}=0.049^{\mathrm{e}}\end{array}$ & $\begin{array}{c}5.426 \pm 0.289 \\
\mathrm{P}=0.003^{\mathrm{c}} \\
\mathrm{P}=0.02^{\mathrm{f}}\end{array}$ & $\begin{array}{c}0.000050 \pm 0.000004 \\
P=0.003^{c}\end{array}$ \\
\hline
\end{tabular}

Results of mRNA NIS expression in the CC cell lines, TFK-1 and HuCCT1, following irradiation with 1, 20 and 60 Gy of ${ }^{131}$ I. The results were obtained at 2, $48 \mathrm{~h}$ and 12 days following irradiation. Results are expressed as the means \pm standard deviation of at least 3 experiments. NIS, natrium-iodide symporter; ${ }^{131} \mathrm{I}$, iodine-131; CC, cholangiocarcinoma. Comparisons are represented as: ${ }^{\mathrm{a} D i f f e r e n c e s}$ between times following exposure, following irradiation with $1 \mathrm{~Gy}$; ${ }^{b}$ differences between times following exposure, following irradiation with 20 Gy; ${ }^{c}$ differences between times following exposure, following irradiation with $60 \mathrm{~Gy}$; ${ }^{\mathrm{d}}$ differences between doses, $2 \mathrm{~h}$ after exposure to irradiation; ${ }^{\mathrm{e}}$ differences between doses, $48 \mathrm{~h}$ following exposure to irradiation; ${ }^{\mathrm{f}}$ differences between doses, 12 days following exposure to irradiation.

rearrangements were found in several chromosomes, particularly in chromosomes $1,2,3,5,11,14,15$ and 17 in the TFK-1 cells and in chromosomes 1, 3, 4, 10, 11 and 14 in the HuCCT1 cells (Fig. 3A and B, respectively). Although some common rearrangements were observed in both cell lines, as far as the deletion of short arm of chromosome 3 and the presence of isochromosome of the short arm of chromosome 5 was concerned, they also presented differences, namely the presence of isochromosomes was more frequently found in the TFK-1 cells. There were no major differences between the cell lines following irradiation, although, by a microscopic inspection, the mitotic index seems to be decreased (data not shown). Table III, presents a summary of the results obtained by karyotyping, aCGH and MS-MLPA for both cholangiocarcinoma cell lines.

Copy number alterations detected by aCGH. The whole genomic approach helped establishing breakpoints, as well as copy number gains and losses in both cell lines (Table III and Fig. 3C). The loss of entire chromosome 18, 6q and 13q, and the gain of 5p, 1q, 3q, 17q and 20q was observed in both cell lines (Fig. 3C). Of note, these two cell lines presented some opposite results, namely the loss of entire chromosome 16 in the HuCCT1 cells and the gain of this chromosome in the TFK-1 cells. Moreover, the X chromosome presented a loss in the TFK-1 cells and a gain in the HuCCT1 cells. TFK-1 cells presented specifically loss of entire 4q, 9p, 21q and most of $9 q, 11 p, 17 p$ and $19 p$ and gain of $15 q$ and partial gain of $1 p, 2 p$ and $3 p$. The HuCCT1 cells exhibited a loss of 4p, 8p and 10p, and a gain of 5q, 7p, 8q, 11q, 12p, 14q and 20p, and almost a total gain of the $\mathrm{Y}$ chromosome. In both cell lines, major differences were not observed considering the genomic results obtained at 60 Gy comparatively to the non-irradiated cells (Table III). Array-CGH and cytogenetic analysis results are congruent as described (Table III).
Copy number alterations and methylation signature based in $M S-M L P A$. We analyzed 25 genes for methylation signature, where the ESR1, PAX5, WT1 and CDH13 genes were methylated in both cell lines without and following irradiation with ${ }^{131} \mathrm{I}$ (Fig. 3D and E). TP73 and MGMT gene promoter methylation was only observed in the TFK-1 cells (Fig. 3D). Following irradiation with 1, 30 and 60 Gy, the TFK-1 cells presented MSH6 gene promoter methylation. The HuCCT1 cells presented MSH6, PAX6, CADM1 and GATA5 gene methylation without and after all doses of ${ }^{131} \mathrm{I}$ (Fig. 3E).

We observed several copy number alterations in both cell lines for the 38 genes analyzed. The TFK-1 cells exhibited less copy number gains than the HuCCT1 cells in these genes (Fig. 3F and G). In both cell lines, we did not observe any variation in the copy numbers for these genes following irradiation. Both cell lines presented copy number gains in GATA5 (20q) and copy number losses in ESRl (6q), RB1 (13q) and TP53 (17p) (Fig. 3F and G). Additionally, the TFK-1 cells exhibited copy number gains in VHL (3p) and CDH13 (16q). Copy number losses were identified in KLLN (10q), PAX6 and $C D 44$ (11p), ATM and CADM1 (11q) and BRCA2 (13q). Homozygous deletion in $C D K N 2 A(9 \mathrm{p})$ and $S T K 11$ (19p) was also found in the TFK-1 cells (Fig. 3F).

Copy number gains in all doses analyzed in the HuCCT1 cells were observed in CDKN2A (9p), PAX5 (9p), MGMT (10q), PAX6, WT1 and CD44 (11p), CADM1 (11q) and $B R C A 1$ (17q). Copy number losses were identified in THBS1 (15q), PYCARD (16p), CDH13 (16q) and STK11 (19p) (Fig. 3G).

Considering simultaneous copy number alterations and methylation status, we verified, in the TFK-1 cells, that ESR 1 gene presented both methylation and copy number loss. Likewise, $C D H 13$ presented both methylation and copy number gain. In the HuCCT1 cells, ESR 1 and $C D H 13$ 

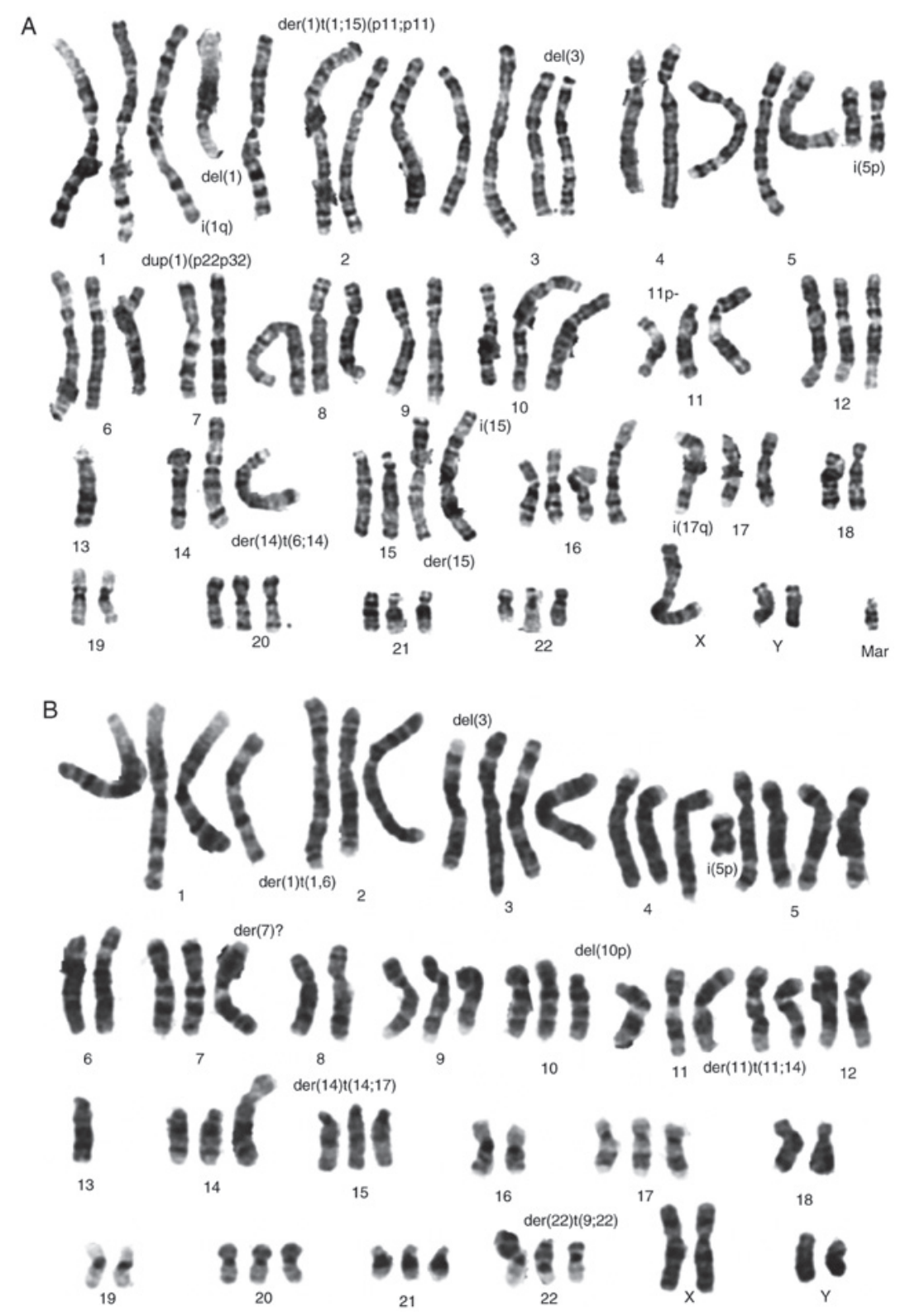

C

Figure 3. (A and B) Cytogenetic analysis, (C) copy number alterations by aCGH. (A and B) Cytogenetic analysis by a karyogram of a representative G-banded metaphase, showing the most frequent imbalances observed in the (A) TKF-1 and (B) HuCCT1 cell lines. (C) Copy number alterations by aCGH, by an idiogram of TKF-1 and HuCCT1 cell lines with genomic characterization obtained by aCGH. TKF-1 cell line is represented in light grey and HuCCT1 cell line in dark grey. Losses are represented on the left and gains on the right. 

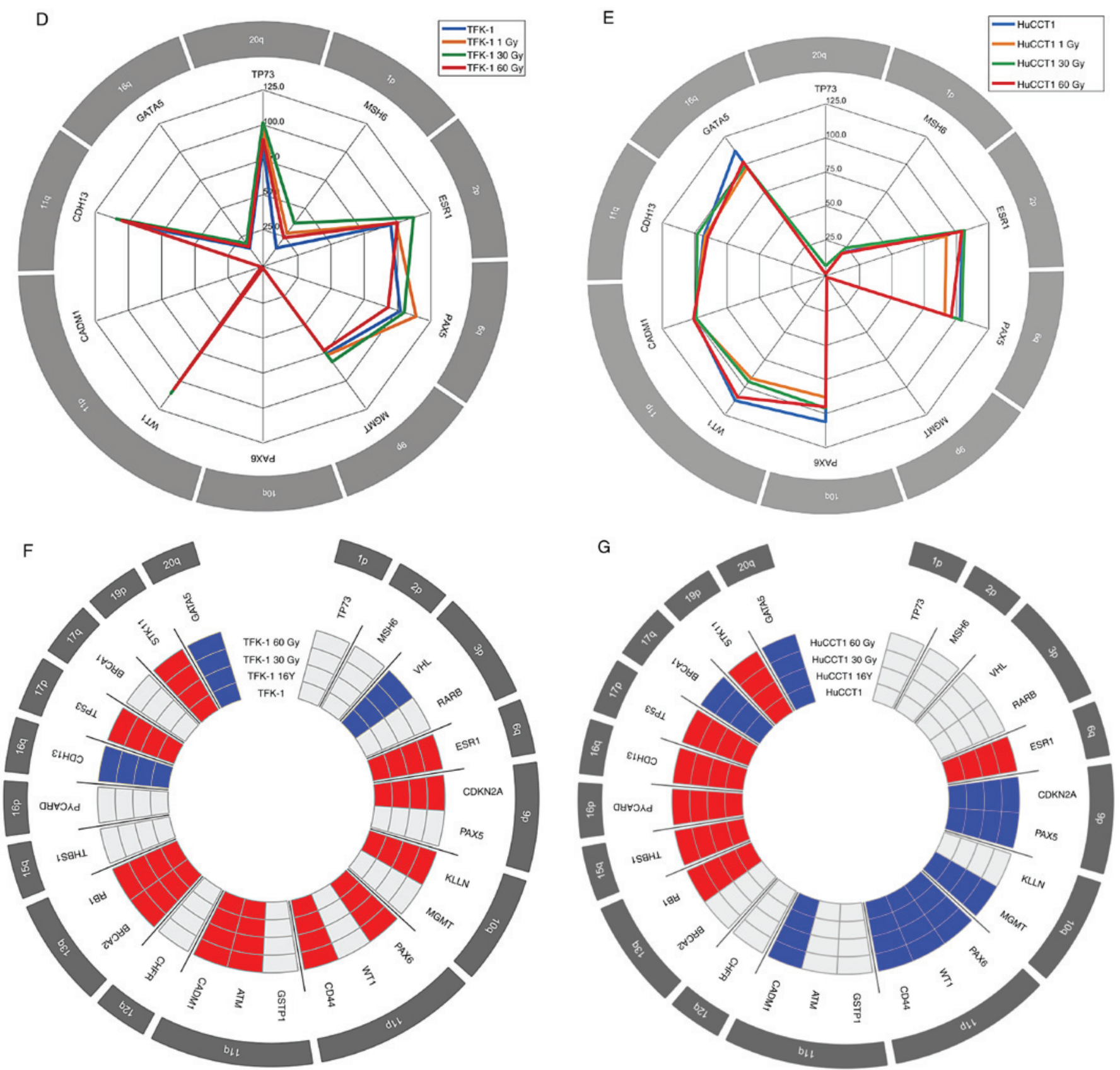

Figure 3. Continued. (D and E) Methylation signature and ( $F$ and G) copy number alterations based on MS-MLPA. Representation of methylated genes in the (D) TFK-1 and (E) HuCCT1 cells following exposure to irradiation based on MS-MLPA analysis. Copy number alterations in (F) TFK-1 and (G) HuCCT1 cells based on MS-MLPA analysis, where red represents losses and blue the gains of genetic material.

presented both methylation and copy number loss. PAX5, $P A X 6, W T 1, C A D M 1$ and GATA5 presented both methylation and copy number gain.

\section{Discussion}

$\mathrm{CC}$ are epithelial neoplasms that originate from cholangiocytes and can occur at any region of the biliary system $(1,36)$. The incidence of $\mathrm{CC}$ is increasing worldwide, being the second most common primary liver malignancy $(1,2,8,36)$.

Surgical resection is the only potential cure for CC (8). Only a few patients are candidates for surgery and the median survival of those with unresectable disease is only
6-12 months (8). Moreover, radiotherapy and chemotherapy can be used only as palliative treatments in these patients (2).

Increasing incidence and the high mortality rate associated wiht CC leads to urgent investigation and the development of novel diagnostic and treatment options. Studies have revealed that human histological samples of CC express NIS at the membrane (10,37). Liu et al (10) demonstrated that histological samples obtained from 20 patients with CC exhibited a strong NIS expression in both the tumor and adjacent non-tumor areas (10). Within bile duct tumor cells, NIS was located at the plasma membrane in 9 patients, and was likely to be functional (10). Additionally, Kim et al (11) demonstrated that only 1 in 60 samples of intrahepatic CC did not express NIS, although this transporter was present at membrane level in only one third of the cases (11). 


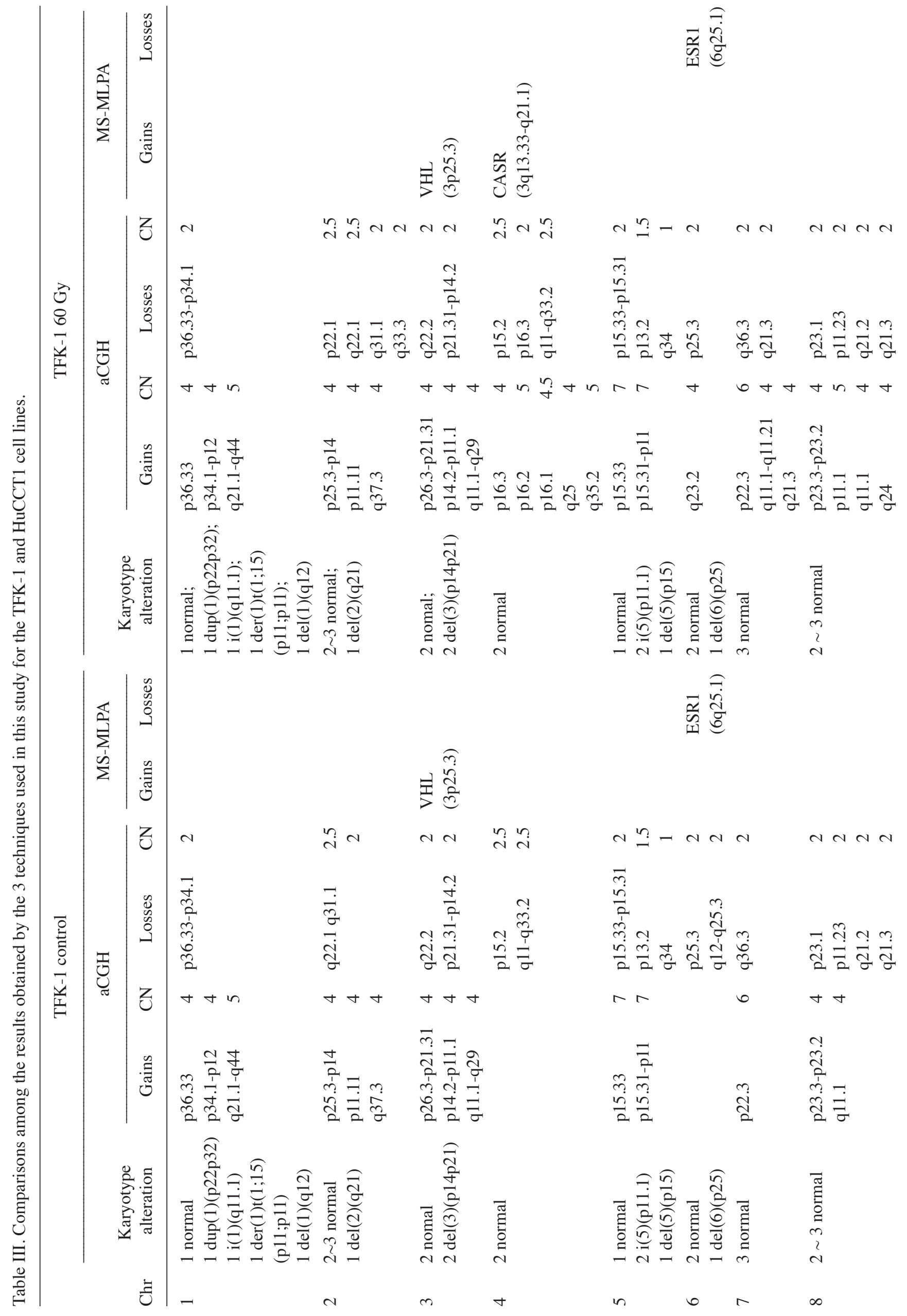




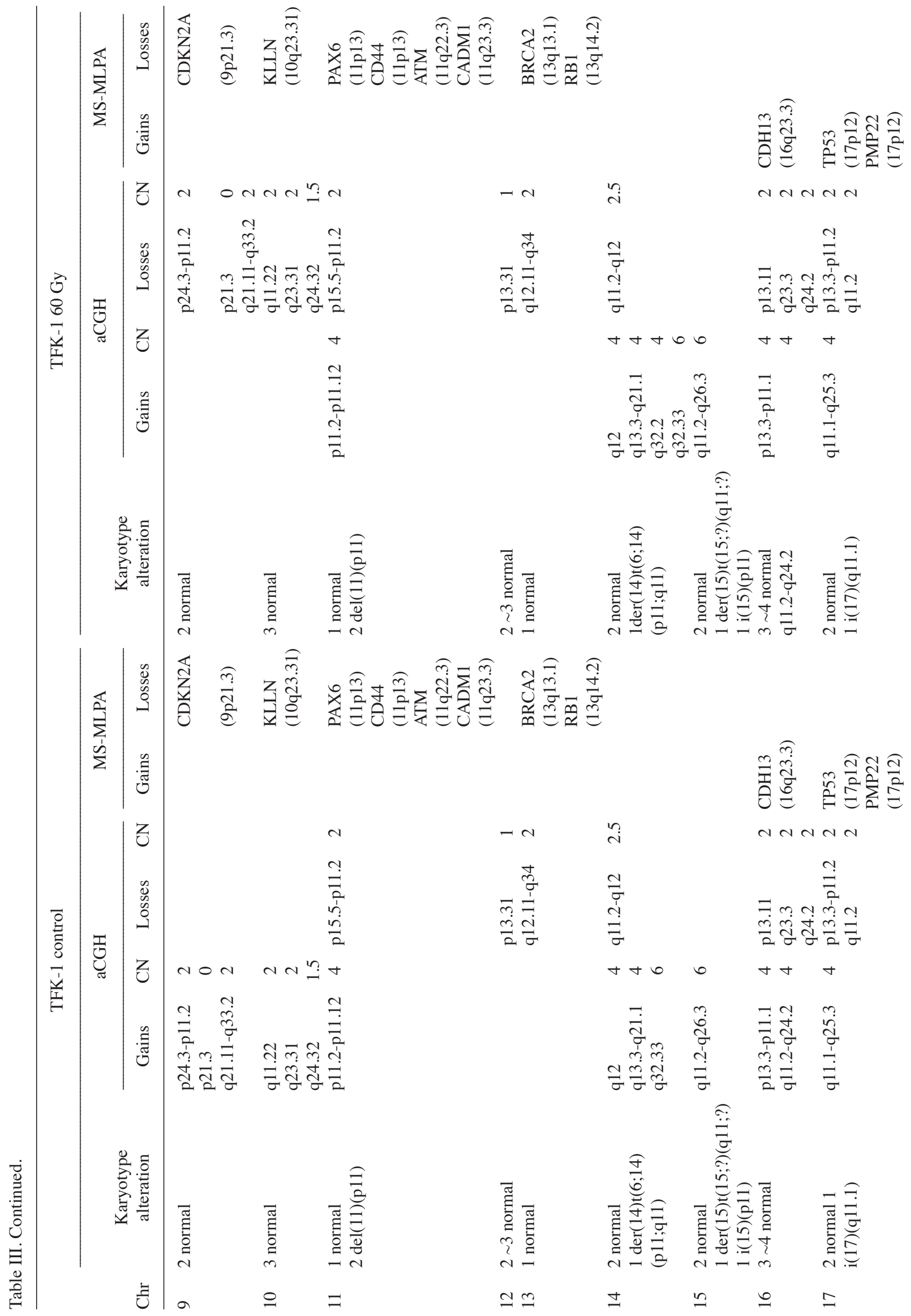




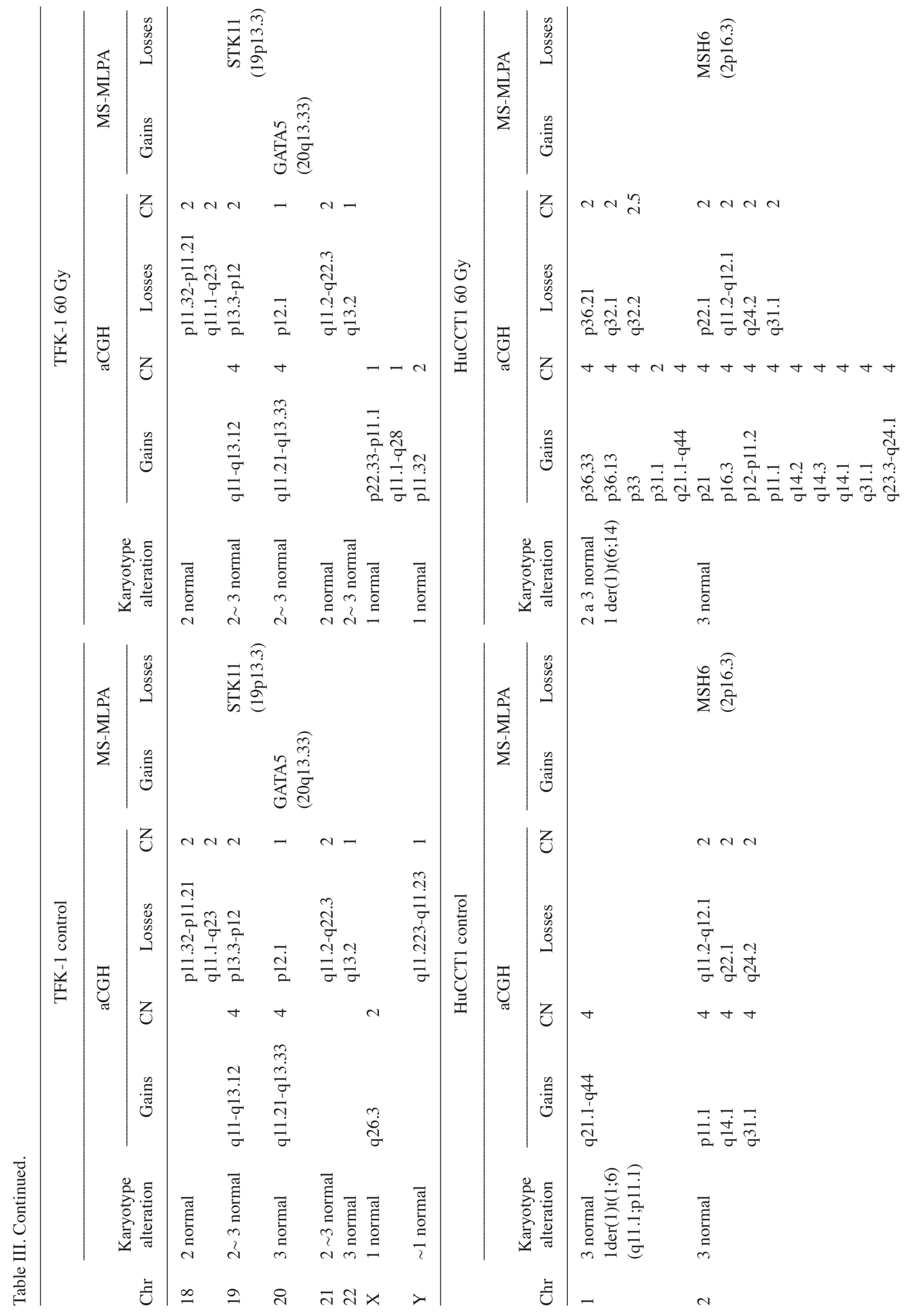




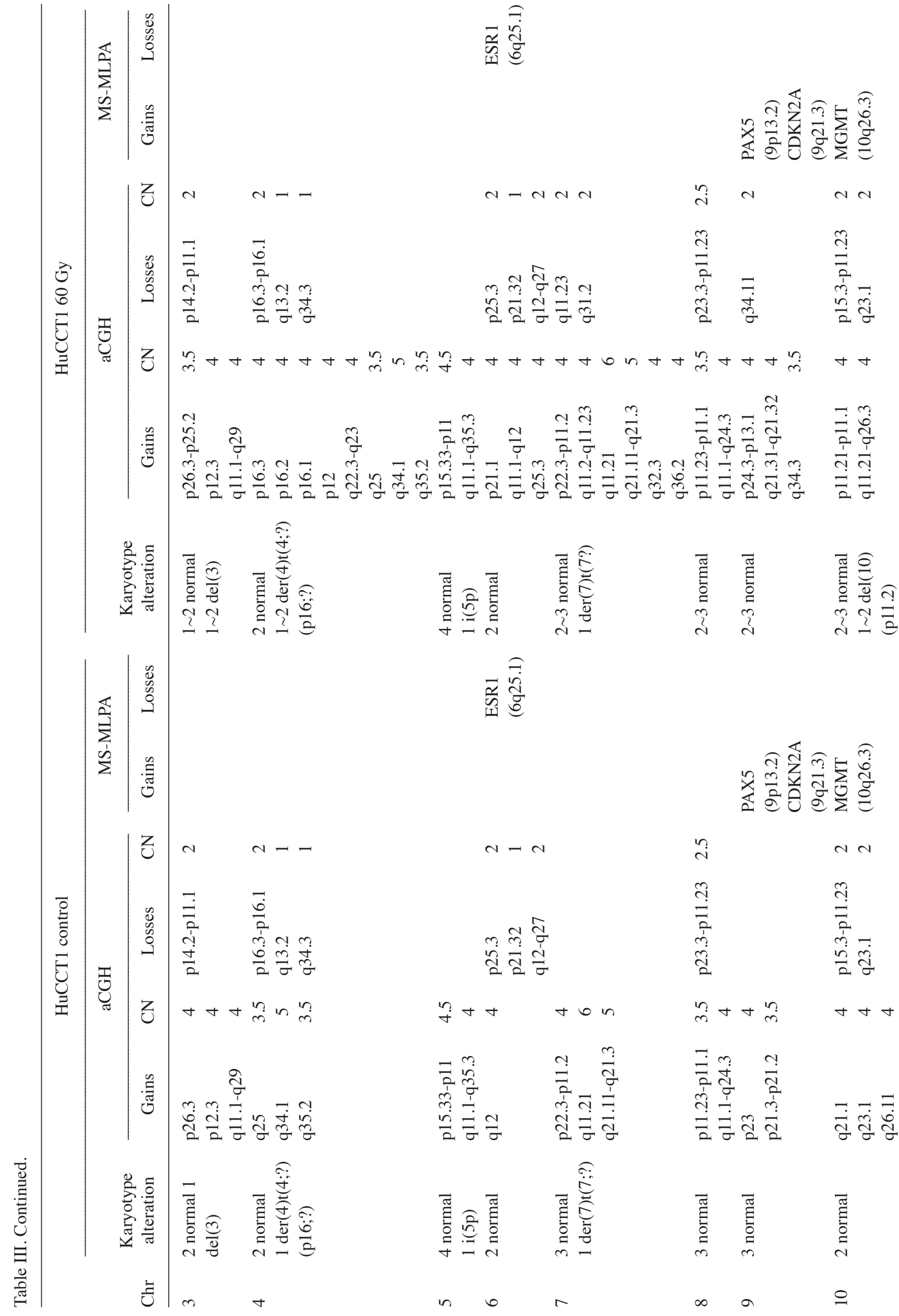




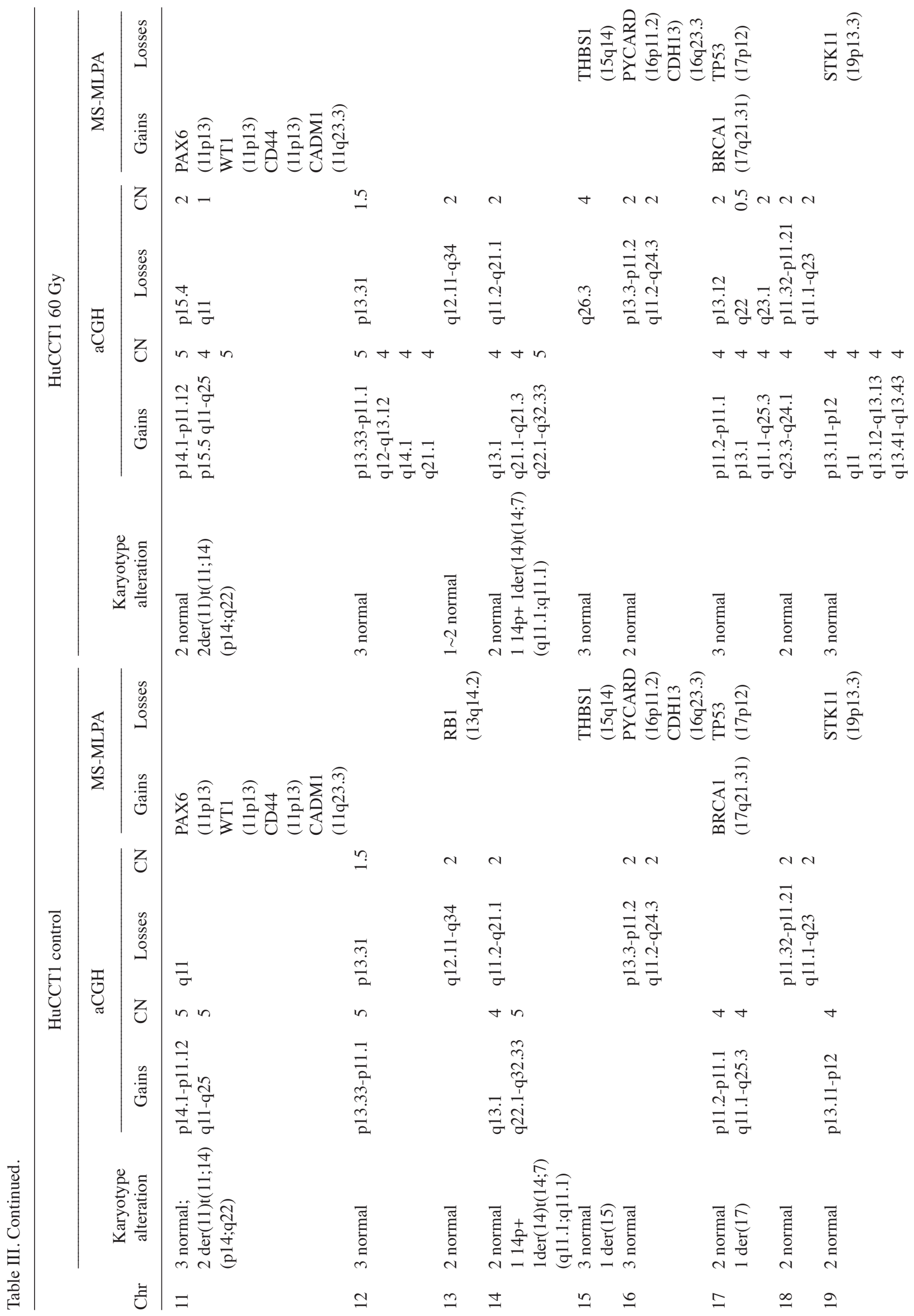




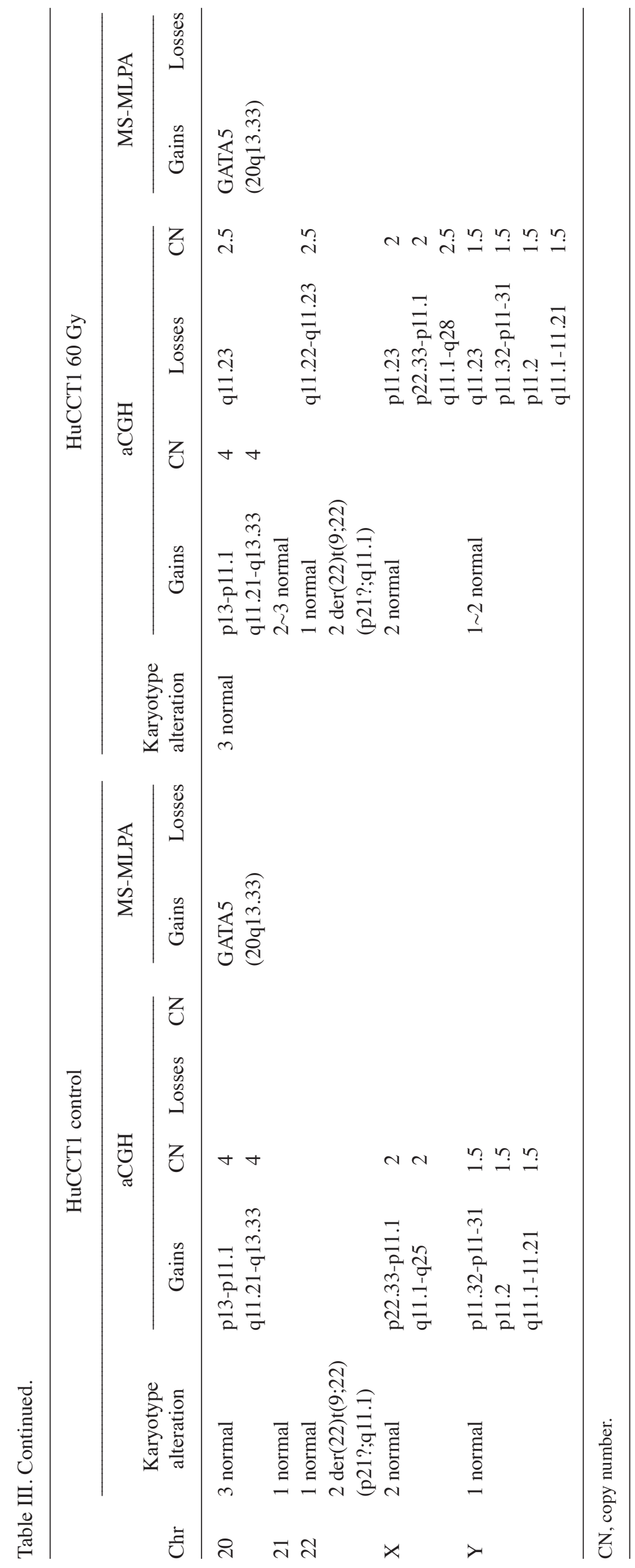


Thus, NIS expression may represent a therapeutic target for $\mathrm{CC}$, since it allows for hte uptake of iodine and its isotopes $(10,11)$, allowing the use of metabolic radiotherapy with ${ }^{131} \mathrm{I}$, frequently used with success for thyroid tumors $(38,39)$. In this study, we aimed to evaluate the potential benefits of metabolic radiotherapy with ${ }^{131} \mathrm{I}$ in extrahepatic (TFK-1) and intrahepatic (HuCCT1) CC cells, using cholangiocytes as controls.

Ionizing radiation (IR) is an effective and common therapeutic approach for cancer $(25,31,40)$. Cancer patients can be treated with radiotherapy alone or in combination with other treatments approaches, such as surgery or chemotherapy. Radiotherapy with IR has direct effects, which targets nuclear DNA, causing damage by direct DNA ionization, and Indirect effects, which include DNA damage by reactive oxygen species (ROS) production, mainly through water radiolysis. ${ }^{131}$ I presents radioactive physical decay half-life of about 8 days, $81 \%$ abundance of $364 \mathrm{keV}$ gamma rays and $89 \%$ abundance beta emission of $606 \mathrm{keV}$, rendering it suitable for metabolic radiotherapy. After the $\mathrm{CC}$ cells and cholangiocytes were exposed to ${ }^{131} \mathrm{I}$, we examined how it can potentially be used to treat $\mathrm{CC}$. A clonogenic assay revealed that the $\mathrm{CC}$ cells were more sensitive to ${ }^{131} \mathrm{I}$, compared with the cholangiocytes. According to the Bergonié and Tribondeau law (41), highly proliferative tissues with high growth rates and metabolic activity are more sensitive to radiation. Thus, cancer cells are more sensitive to ${ }^{131}$ I compared to cholangiocytes. As a metabolic radiotherapy agent, ${ }^{\mathrm{I} 31} \mathrm{I}$ is uptaken by cells after administration. Therefore, NIS at the cell membrane can be targeted; ${ }^{131} \mathrm{I}$ may be a metabolic radiotherapy agent for the treatment of CC. Some studies have suggested the use of ${ }^{131} \mathrm{I}$ in intrahepatic CC, as human samples of this type of tumor hihly expressed NIS. However, to the best of our knowledge there are no data available concerning extrahepatic $\mathrm{CC}$ human samples (10). The results of this study revealed an increasing NIS expression in both the intra- and extrahepatic cancer cells compared to the cholangiocytes. This fact demonstrates that ${ }^{131}$ I may be a modality with a type of selectivity, leading to a lower NIS expression when comparing the H69 with the CC cells (Fig. 1). This suggests great potential for ${ }^{131} \mathrm{I}$, since NIS expression is upregulated in various types of cancer, including liver cancer $(12,37)$. Moreover, NIS can participate in cell migration and invasion during carcinogenesis (42-46). As regards gene expression, there was a higher NIS expression in the TFK-1 cells compared with the HuCCT1 cells. This expression decreases with increasing doses and increases with time following exposure. Studies have reported different molecules that influence NIS expression, such as pregnancy-associated hormones, among others $(47,48)$. These molecules, when suppressed, such as the MAP kinase and PI3K/Akt pathways, and HDAC, can induce an increase in NIS expression. Considering the effects of IR, the results of clonogenic assay demonstrated that ${ }^{131}$ I decreased cell survival. Thus, this assay provides indirect information about proliferation, differentiation and cell cycle progression, as PI3K/Akt signaling affects cell growth, survival, differentiation and proliferation (49).

The findings of this study demonstrated that the CC cells could uptake ${ }^{131} \mathrm{I}$. Our results revealed that both cancer cell lines could uptake ${ }^{131} \mathrm{I}$, which was higher in the TFK-1 cells, associated with the existence of NIS expression, data corroborated by the study of Liu et al (42).
As regards NIS expression, a selectivity for ${ }^{131} \mathrm{I}$ is another explanation for the higher survival rate of cholangiocytes, compared to the CC cells. The results confirmed that ${ }^{131} \mathrm{I}$ affected all cell lines, with a higher expression in the cancer cells. The results obtained by clonogenic assay corroborated those stated by the Bergonié and Tribondeau law (41). Cell viability analyses demonstrated a significant decrease in TFK-1 cell viability, with a significant increase in the apoptotic cells. As regards the HuCCt1 cells, there were no alterations in cell viability, apart from a slightly increase in initial cell apoptosis. Cell cycle analysis revealed that there were no alterations compared with the control, with most of the cells presenting in the $\mathrm{G}_{0} / \mathrm{G}_{1}$ phase, a quiescent phase.

The molecular mechanisms responsible for carcinogenesis and tumor progression are poorly characterized in intrahepatic CC. The management and treatment of this type of cancer remains a challenge, due to the late diagnosis and lack of effective treatments, and a lack of promising novel therapeutic approaches. This can be due to existing data indicating that intrahepatic CC is a heterogeneous tumor (50). This heterogeneity is sustained on alterations of inflammatory pathways as the continuous production of inflammatory cytokines, oxidative stress by the induction of inducible nitric oxide synthase (iNOS) that leads to oxidative and nitrosative DNA damage, as well as an increased cell turnover and inhibition of DNA repair. This type of tumor can be characterized as a stepwise cancer model, where the accumulation of inflammatory-mediated genetic and epigenetic alterations can explain dysplastic lesions that can lead to cancer (51). In this study, cytogenetic, genomic and methylation approaches revealed several numerical and structural chromosomal abnormalities and methylated genes in the CC cells. The TFK-1 cells presented more structural alterations, such as isochromosomes and specifically exhibited the loss of 4q, 9p, 9q, 11p, 17p, 19p and 21q, and the gain of 1p, $2 p, 3 p$ and $15 q$. The HuCCT1 cells exhibited the loss of $4 p, 8 p$ and 10p, and the gain of 5q, 7p, 8q, 11q, 12p, 14q and 20p, and almost a total gain of the $\mathrm{Y}$ chromosome. This comprehensive characterization of $\mathrm{CC}$ cells may contribute to enriching the resources available for $\mathrm{CC}$ research. However, it is important to continue to describe the possible effects induced by ${ }^{131} \mathrm{I}$ on cholangiocarcinoma, namely its influence on oxidative stress, genotoxicity. Moreover, the influence of NIS gene expression manipulation on the effects of ${ }^{31} \mathrm{I}$ on CC cells, as well as the effects of ${ }^{131} \mathrm{I}$ therapy on animal models remains unclear, and future studies are warranted to address these issues.

In conclusion, the results of this study revealed the great significance of NIS expression in the therapeutic response to ${ }^{131}$ I. We demonstrated that NIS expression was higher following the irradiation of the CC cells compared to cholangiocytes, which indicates that NIS may be a specific therapeutic target for $\mathrm{CC}$. We demonstrated that ${ }^{131} \mathrm{I}$ decreased $\mathrm{CC}$ cell viability and survival in a cell type- and dose-dependent manner. The different cellular responses to treatment may be due to differences in gene expression and methylation profiles. Thus, it was demonstrated that NIS in may be crucial for the efficacy of ${ }^{131}$ I-based therapy.

\section{Acknowledgements}

Not applicable. 


\section{Funding}

This study was supported by the Foundation for Science and Technology (FCT), Portugal (Strategic Projects UID/NEU/04539/2013 and UID/NEU/04539/2019) and COMPETE-FEDER (POCI-01-0145-FEDER-007440), a PhD grant from FCT to RT (SFRH/BD/116794/2016), a research fellowship 'Bolsa Dr Rocha Alves' from Liga Portuguesa Contra o Cancro to Ricardo Martins, and a grant from 'Conselho Nacional de Desenvolvimento Científico e Tecnológico (CNPq, Brazil)’ to IB (400988/2016-0).

\section{Availability of data and materials}

The datasets used and/or analyzed during the current study are available from the corresponding author on reasonable request.

\section{Authors' contributions}

The authors AFB, AMA, JBM, IMC, DMJ, JGT and MFB contributed to the conception, design and follow-up of the work, as well as to the writing, drafting, revising, editing and reviewing of the manuscript. The authors ASP, ACR, AF, ML, FC and RM contributed to the acquisition, analysis, and interpretation of data for the study related to NIS protein expression, uptake assays, clonogenic assays, as well as to the writing, drafting, revising, editing and reviewing of the manuscript. The authors RT, TP and FC contributed to the acquisition, analysis, and interpretation of data for the study related to NIS protein expression, uptake assays, as well as to the writing, drafting, revising, editing and reviewing of the manuscript. The authors JR and IPR contributed to the acquisition, analysis and interpretation of data for the study related to the karyotyping, array CGH and MS-MLPA assays, as well as to the writing, drafting, revising, editing and reviewing of the manuscript. ACG and ABSR contributed to the acquisition, analysis and interpretation of data for the study related to the flow cytometry assays, as well as to the writing, drafting, revising, editing and reviewing of the manuscript. IB, DS and RFF contributed to the acquisition, analysis and interpretation of data for the study related to mRNA NIS expression experiment, as well as to the writing, drafting, revising, editing and reviewing of the manuscript. The authors RT, ASP and FC also contributed to the statistical analysis of the results. All the authors approved the final version of the manuscript to be published and agree to be accountable for all aspects of this work in ensuring that questions related to the accuracy or integrity of any part of this work are appropriately investigated and resolved.

\section{Ethics approval and consent to participate}

The present study was approved by the Ethics in Research Committee of the Faculty of Medicine of the University of Coimbra (ref: 033-CE-2015) and written informed consent from the patients was obtained. All the experiments were performed according to the regulations of Helsinki Declaration.

\section{Patient consent for publication}

Not applicable.

\section{Competing interests}

The authors declare that they have no competing interests.

\section{References}

1. Olnes MJ and Erlich R: A review and update on cholangiocarcinoma. Oncology 66: 167-179, 2004.

2. Brito AF, Abrantes AM, Encarnação JC, Tralhão JG and Botelho MF: Cholangiocarcinoma: From molecular biology to treatment. Med Oncol 32: 245, 2015.

3. DeOliveira ML, Cunningham SC, Cameron JL, Kamangar F, Winter JM, Lillemoe KD, Choti MA, Yeo CJ and Schulick RD: Cholangiocarcinoma: Thirty-one-year experience with 564 patients at a single institution. Ann Surg 245: 755-762, 2007.

4. Nakeeb A, Pitt HA, Sohn TA, Coleman J, Abrams RA, Piantadosi S, Hruban RH, Lillemoe KD, Yeo CJ and Cameron JL: Cholangiocarcinoma: A spectrum of intrahepatic, perihilar, and distal tumors. Ann. Surg 224: 463-475, 1996.

5. Shaib Y and El-Serag HB: The epidemiology of cholangiocarcinoma. Semin Liver Dis 24: 115-125, 2004.

6. He XR and Wu XP: Difference in biological characteristics and sensitivity to chemotherapy and radiotherapy between intrahepatic and extrahepatic cholangiocarcinoma cells in vitro. Chin Med Sci J 23: 54-59, 2008.

7. Carriaga MT and Henson DE: Liver, gallbladder, extrahepatic bile ducts, and pancreas. Cancer 75 (1 Suppl): S171-S190, 1995.

8. Aljiffry M, Walsh MJ and Molinari M: Advances in diagnosis, treatment and palliation of cholangiocarcinoma: 1990-2009. World J Gastroenterol 15: 4240-4262, 2009.

9. Nathan H, Aloia TA, Vauthey JN, Abdalla EK, Zhu AX, Schulick RD, Choti MA and Pawlik TM: A proposed staging system for intrahepatic cholangiocarcinoma. Ann Surg Oncol 16: 14-22, 2009.

10. Liu B, Hervé J, Bioulac-Sage P, Valogne Y, Roux J, Yilmaz F, Boisgard R, Guettier C, Calès P, Tavitian B, et al: Sodium iodide symporter is expressed at the preneoplastic stages of liver carcinogenesis and in human cholangiocarcinoma. Gastroenterology 132: 1495-1503, 2007.

11. Kim JH, Han SY, Lee SW, Baek YH, Kim HY, Kim JH, Jeong JS, Roh YH, Kim YH, Park BH, et al: Sodium iodide symporter and phosphatase and tensin homolog deleted on chromosome ten expression in cholangiocarcinoma analysis with clinicopathological parameters. Gut Liver 6: 374-380, 2012.

12. Guerrieri F, Piconese S, Lacoste C, Schinzari V, Testoni B, Valogne Y, Gerbal-Chaloin S, Samuel D, Bréchot C, Faivre J and Levrero M: The sodium/iodide symporter NIS is a transcriptional target of the p53-family members in liver cancer cells. Cell Death Dis 4: e807, 2013.

13. Riesco-Eizaguirre G and Santisteban P: A perspective view of sodium iodide symporter research and its clinical implications. Eur J Endocrinol 155: 495-512, 2006.

14. Kogai T and Brent GA: The sodium iodide symporter (NIS): Regulation and approaches to targeting for cancer therapeutics. Pharmacol Ther 135: 355-370, 2012.

15. Dohán O, De la Vieja A, Paroder V, Riedel C, Artani M, Reed M, Ginter CS and Carrasco N: The sodium/iodide symporter (NIS): Characterization, regulation, and medical significance. Endocr Rev 24: 48-77, 2003

16. Lacroix L, Mian C, Caillou B, Talbot M, Filetti S, Schlumberger M and Bidart JM: $\mathrm{Na}(+) / \mathrm{I}(-)$ symporter and Pendred syndrome gene and protein expressions in human extra-thyroidal tissues. Eur J Endocrinol 144: 297-302, 2001.

17. Spitzweg C, Dutton CM, Castro MR, Bergert ER, Goellner JR, Heufelder AE and Morris JC: Expression of the sodium iodide symporter in human kidney. Kidney Int 59: 1013-1023, 2001.

18. Wapnir IL, van de Rijn M, Nowels K, Amenta PS, Walton K, Montgomery K, Greco RS, Dohán O and Carrasco N: Immunohistochemical profile of the sodium/iodide symporter in thyroid, breast, and other carcinomas using high density tissue microarrays and conventional sections. J Clin Endocrinol Metab 88: 1880-1888, 2003.

19. Altorjay A, Dohán O, Szilágyi A, Paroder M, Wapnir IL and Carrasco N: Expression of the Na+/I- symporter (NIS) is markedly decreased or absent in gastric cancer and intestinal metaplastic mucosa of Barrett esophagus. BMC Cancer 7: 5, 2007. 
20. Gaertner FC, Rohde F, Mueller J, Blechert B, Janssen KP and Essler M: Endogenous expression of the sodium iodide symporter mediates uptake of iodide in murine models of colorectal carcinoma. Int J Cancer 125: 2783-2791, 2009.

21. Parthasarathy KL and Crawford ES: Treatment of thyroid carcinoma: Emphasis on high-dose 131 I outpatient therapy. J Nucl Med Technol 30: 165-175, 2002.

22. Mansi L, Moncayo R, Cuccurullo V, Dottorini ME and Rambaldi PF: Nuclear medicine in diagnosis, staging and follow-up of thyroid cancer. Q J Nucl Med Mol Imaging 48: 82-95, 2004

23. Grubman S, Perrone RD, Lee DW, Murray SL, Rogers LC, Wolkoff LI, Mulberg AE, Cherington V and Jefferson DM: Regulation of intracellular $\mathrm{pH}$ by immortalized human intrahepatic biliary epithelial cell lines. Am J Physiol 266: G1060-G1070, 1994.

24. Hohenester S, Maillette de Buy Wenniger L, Jefferson DM, Oude Elferink RP and Beuers U: Biliary bicarbonate secretion constitutes a protective mechanism against bile acid-induced injury in man. Dig Dis 29: 62-65, 2011.

25. Gomes AR, Abrantes AM, Brito AF, Laranjo M, Casalta-Lopes JE, Gonçalves AC, Sarmento-Ribeiro AB Botelho MF and Tralhão JG: Influence of P53 on the radiotherapy response of hepatocellular carcinoma. Clin Mol Hepatol 21: 257-267, 2015.

26. Abrantes AM, Serra ME, Gonçalves AC, Rio J, Oliveiros B, Laranjo M, Rocha-Gonsalves AM, Sarmento-Ribeiro AB and Botelho MF: Hypoxia-induced redox alterations and their correlation with 99mTc-MIBI and 99mTc-HL-91 uptake in colon cancer cells. Nucl Med Biol 37: 125-132, 2010.

27. Brito AF, Abrantes AM, Ribeiro M, Oliveira R, Casalta-Lopes J Gonçalves AC, Sarmento-Ribeiro AB, Tralhão JG and Botelho MF: Fluorine-18 fluorodeoxyglucose uptake in hepatocellular carcinoma: Correlation with glucose transporters and p53 expression. J Clin Exp Hepatol 5: 183-189, 2015.

28. Levenberg K: A method for the solution of certain non-linear problems in least squares. Quartly of Applied Mathematics 2: 164-168, 1944.

29. Marquardt DW: An algorithm for least-squares estimation of non-linear parameters. J Soc Industrial Appl Mathematics 11: 431-441, 1963

30. Kuchar M, Oliveira MC, Gano L, Santos I and Kniess T: Radioiodinated sunitinib as a potential radiotracer for imaging angiogenesis-radiosynthesis and first radiopharmacologica evaluation of 5-[125I]Iodo-sunitinib. Bioorg Med Chem Lett 22: $2850-2855,2012$

31. Mendes F, Sales T, Domingues C, Schugk S, Abrantes AM, Gonçalves AC, Teixo R, Silva R, Casalta-Lopes J, Rocha C, et al: Effects of X-radiation on lung cancer cells: The interplay between oxidative stress and P53 levels. Med Oncol 32: 266, 2015.

32. Schmittgen TD and Livak KJ: Analyzing real-time PCR data by the comparative CT method. Nat Protoc 3: 1101-1108, 2008.

33. Ribeiro IP, Rodrigues JM, Mascarenhas A, Kosyakova N, Caramelo F, Liehr T, Melo JB and Carreira IM: Cytogenetic, genomic, and epigenetic characterization of the HSC-3 tongue cell line with lymph node metastasis. J Oral Sci 60: 70-81, 2018.

34. Ribeiro IP, Caramelo F, Esteves L, Menoita J, Marques F, Barroso L, Miguéis J, Melo JB and Carreira IM: Genomic predictive model for recurrence and metastasis development in head and neck squamous cell carcinoma patients. Sci Rep 7: 13897, 2017.

35. Ribeiro IP, Caramelo F, Marques F, Domingues A, Mesquita M, Barroso L, Prazeres H, Julião MJ, Baptista IP, Ferreira A, et al: WT1, MSH6, GATA5 and PAX5 as epigenetic oral squamous cell carcinoma biomarkers-a short report. Cell Oncol (Dordr) 39: $575-582,2016$
36. Malhi $\mathrm{H}$ and Gores GJ: Review article: The modern diagnosis and therapy of cholangiocarcinoma. Aliment Pharmacol Ther 23: 1287-1296, 2006.

37. Micali S, Bulotta S, Puppin C, Territo A, Navarra M, Bianchi G, Damante G, Filetti S and Russo D: Sodium iodide symporter (NIS) in extrathyroidal malignancies: Focus on breast and urological cancer. BMC Cancer 14: 330, 2014.

38. Chen L, Altmann A, Mier W, Eskerski H, Leotta K, Guo L, Zhu R and Haberkorn U: Radioiodine therapy of hepatoma using targeted transfer of the human sodium/iodide symporter gene. J Nucl Med 47: 854-862, 2006.

39. Verburg FA, Brans B and Mottaghy FM: Molecular nuclear therapies for thyroid carcinoma. Methods 55: 230-237, 2011.

40. Marques IA, Neves AR, Abrantes AM, Pires AS, Tavares-da-Silva E, Figueiredo A and Botelho MF: Targeted alpha therapy using Radium-223: From physics to biological effects. Cancer Treat Rev 68: 47-54, 2018.

41. Haber $\mathrm{AH}$ and Rothstein BE: Radiosensitivity and rate of cell division: 'Law of bergonié and tribondeau'. Science 163: 1338-1339, 1969.

42. Liu L, Li D, Chen Z, Yang J, Ma Y, Cai H, Shan C, Lv Z and Zhang X: Wild-Type P53 induces sodium/iodide symporter expression allowing radioiodide therapy in anaplastic thyroid cancer. Cell Physiol Biochem 43: 905-914, 2017.

43. Moon DH, Lee SJ, Park KY, Park KK, Ahn SH, Pai MS, Chang H, Lee HK and Ahn IM: Correlation between 99mTc-pertechnetate uptakes and expressions of human sodium iodide symporter gene in breast tumor tissues. Nucl Med Biol 28: 829-834, 2001.

44. Cianfarani F, Baldini E, Cavalli A, Marchioni E, Lembo L, Teson M, Persechino S, Zambruno G, Ulisse S, Odorisio T and D'Armiento M: TSH receptor and thyroid-specific gene expression in human skin. J Invest Dermatol 130: 93-101, 2010.

45. Damle AA, Narkar AA and Badwe RA: Radioiodide uptake and sodium iodide symporter expression in breast carcinoma. Indian J Exp Biol 49: 416-422, 2011

46. Lacoste C, Hervé J, Bou Nader M, Dos Santos A, Moniaux N, Valogne Y, Montjean R, Dorseuil O, Samuel D, Cassio D, et al: Iodide transporter NIS regulates cancer cell motility and invasiveness by interacting with the rho guanine nucleotide exchange factor LARG. Cancer Res 72: 5505-5515, 2012.

47. Alotaibi H, Tuzlakoğlu-Öztürk M and Tazebay UH: The thyroid $\mathrm{Na}$ /I- symporter: Molecular characterization and genomic regulation. Mol Imaging Radionucl Ther 26 (Suppl 1): S92-S101, 2017.

48. Lindenthal S, Lecat-Guillet N, Ondo-Mendez A, Ambroise Y, Rousseau B and Pourcher T: Characterization of small-molecule inhibitors of the sodium iodide symporter. J Endocrinol 200: 357-365, 2009.

49. Khan KH, Yap TA, Yan L and Cunningham D: Targeting the PI3K-AKT-mTOR signaling network in cancer. Chin J Cancer 32: 253-265, 2013.

50. Liau JY, Tsai JH, Yuan RH, Chang CN, Lee HJ and Jeng YM: Morphological subclassification of intrahepatic cholangiocarcinoma: Etiological, clinicopathological and molecular features. Mod Pathol 27: 1163-1173, 2014.

51. Kumar M, Zhao X and Wang XW: Molecular carcinogenesis of hepatocellular carcinoma and intrahepatic cholangiocarcinoma: One step closer to personalized medicine? Cell Biosci 1: 5, 2011.

This work is licensed under a Creative Commons Attribution-NonCommercial-NoDerivatives 4.0 International (CC BY-NC-ND 4.0) License. 